\title{
1.90-1.88 GA ARC AND BACK-ARC BASIN IN THE ORIJ ÄRVI AREA, SW FINLAND
}

\author{
MARKKU VÄISÄNEN AND IRMELI MÄNTTÄRI
}

VÄISÄNEN, MARKKU and MÄNTTÄRI, IRMELI 2002. 1.90-1.88 Ga arc and back-arc basin in the Orijärvi area, SW Finland. Bulletin of the Geological Society of Finland 74, Parts 1-2, 185-214.

The Orijärvi area within the Uusimaa Belt is a key area in resolving the stratigraphy and tectonic setting of the Southern Svecofennian Arc Complex in southern Finland. Based on field relationships, geochemistry and radiometric age determinations, the area can be divided into four formations. The bimodal Orijärvi formation, lowermost in stratigraphy, is exposed in an antiform containing the synvolcanic Orijärvi granodiorite in its core. Basalts have high LILE/HFSE ratios with pronounced negative $\mathrm{Nb}$-Ta anomalies. The basalts in the lower part of the Orijärvi formation are geochemically less evolved than the basalts and basaltic andesites at higher levels. A rhyolite from a low stratigraphic level in the Orijärvi formation yielded a U-Pb zircon age of 1895.3 \pm 2.4 Ma. The Kisko formation stratigraphically overlies the Orijärvi formation and the compositions of the volcanic rocks range from basalts to rhyolites. These mafic and intermediate rocks also show high LILE/HFSE ratios but the total element abundances are higher and show a more pronounced LREE enrichment, compared to the Orijärvi formation, indicating an evolved magma system. A dacite from the upper part of the Kisko formation yielded a U-Pb zircon age of 1878.2 \pm 3.4 Ma. The Salittu formation probably overlies the Kisko formation. It mainly comprises picrites and tholeiitic pillow lavas with mica gneisses and minor marbles as intercalations. It differs from the underlying formations showing higher $\mathrm{Mg}$, $\mathrm{Ti}$ and $\mathrm{Zr}$ contents and higher LILE/HFSE ratios. The major and trace element compositions indicate an oceanic affinity. The Toija formation evidently underlies the Salittu formation and comprises mafic pillow lavas, rhyolites, marbles, and one picritic horizon. The geochemical characteristics are transitional between the Salittu and Orijärvi/Kisko formations. All the formations contain both concordant and crosscutting intrusive rocks, some of which are comagmatic with the volcanic rocks. 
In tectonomagmatic discrimination diagrams the Orijärvi and Kisko formations plot in the island arc field and the Salittu formation plots in the E-MORB field. High LILE/HFSE ratios, typical of subduction-related volcanic rocks, characterize the Orijärvi and Kisko formations, whereas such a subduction component is less prominent in the Toija formation and is missing in the Salittu formation. Geochemistry and age relationships suggest that the Orijärvi formation was formed during the initial stages of volcanic arc evolution in an extensional tectonic regime, and the Kisko formation represents a mature stage of arc evolution. Subsequent extension of the island arc is manifested by the ultramafic/ mafic Salittu formation with E-MORB-like chemistry, interpreted to indicate a back-arc basin. The Toija formation might represent an initial stage of back-arc rifting.

Key words: metavolcanic rocks, igneous rocks, geochemistry, tectonics, island arcs, back-arc basins, absolute age, U/Pb, Paleoproterozoic, Svecofennian, Orijärvi, Kisko, Salittu, Toija, Finland

Markku Väisänen: Department of Geology, University of Turku, FIN-20014 Turku, Finland

Corresponding author.

E-mail: markku.vaisanen@utu.fi

Irmeli Mänttäri: Geological Survey of Finland, PO Box 96, FIN-02151 Espoo, Finland

\section{INTRODUCTION}

The Palaeoproterozoic Svecofennian volcanic and sedimentary belts in Finland have been interpreted as island arc systems reminiscent of modern equivalents since Anna Hietanen's (1975) original idea. Today, geochemical, radiometric and other geological constraints indicate that the Finnish part of the Svecofennian Orogen consists of two main arc complexes, called the Central Svecofennian Arc Complex (CSAC) and the Southern Svecofennian Arc Complex (SSAC) by Väisänen et al. (2002). These may also include formations older than the juvenile island arcs (e.g. Lahtinen 1994, 1996, Lahtinen \& Huhma 1997, Nironen 1997, Korsman et al. 1999, Nironen et al. 2000). These two arc complexes are separated by an inferred suture zone (Lahtinen 1996, Nironen et al. 2000).

The Orijärvi area in SW Finland (Fig. 1) is a key area for studying the volcanic formations in the SSAC because of its lower metamorphic grade and degree of deformation compared to the surrounding areas (Schreurs \& Westra 1986, Ploegsma \& Westra 1990). The area has been a target for exploration for ca. 300 years since the first iron mine was opened in $17^{\text {th }}$ century in Malmberget, near Lake Määrjärvi. The Orijärvi $\mathrm{Cu}-(\mathrm{Zn})$ deposit was discovered in 1757 starting a still ongoing geological interest in the area. In 1914, Pentti Eskola published his classical article on the petrology of igneous and metamorphic rocks in the Orijärvi area. That paper formed the basis for his well known theory of mineral equilibria and metamorphic facies (Eskola 1915), which still remains in metamorphic petrology. These two papers have directly or indirectly influenced most of the subsequent geological investigation in this area. In particular, the cordierite- and anthophyllite-bearing altered volcanic rocks and their relationships to sulphide mineralizations have gained repeated interest (e.g. Tuominen \& Mikkola 1950, Latvalahti 1979, Colley \& Westra 1987, Schumacher \& Czank 1987, Mäkelä 1989, Schneiderman \& Tracy 1991, Smith et al. 1992, Rajavuori \& Kriegsman 2000).

The emphasis of investigations on altered rocks close to mineralizations and on regional rock units without a clear stratigraphic control have hampered the use of the published data for regional interpretations. The other problem has been the 


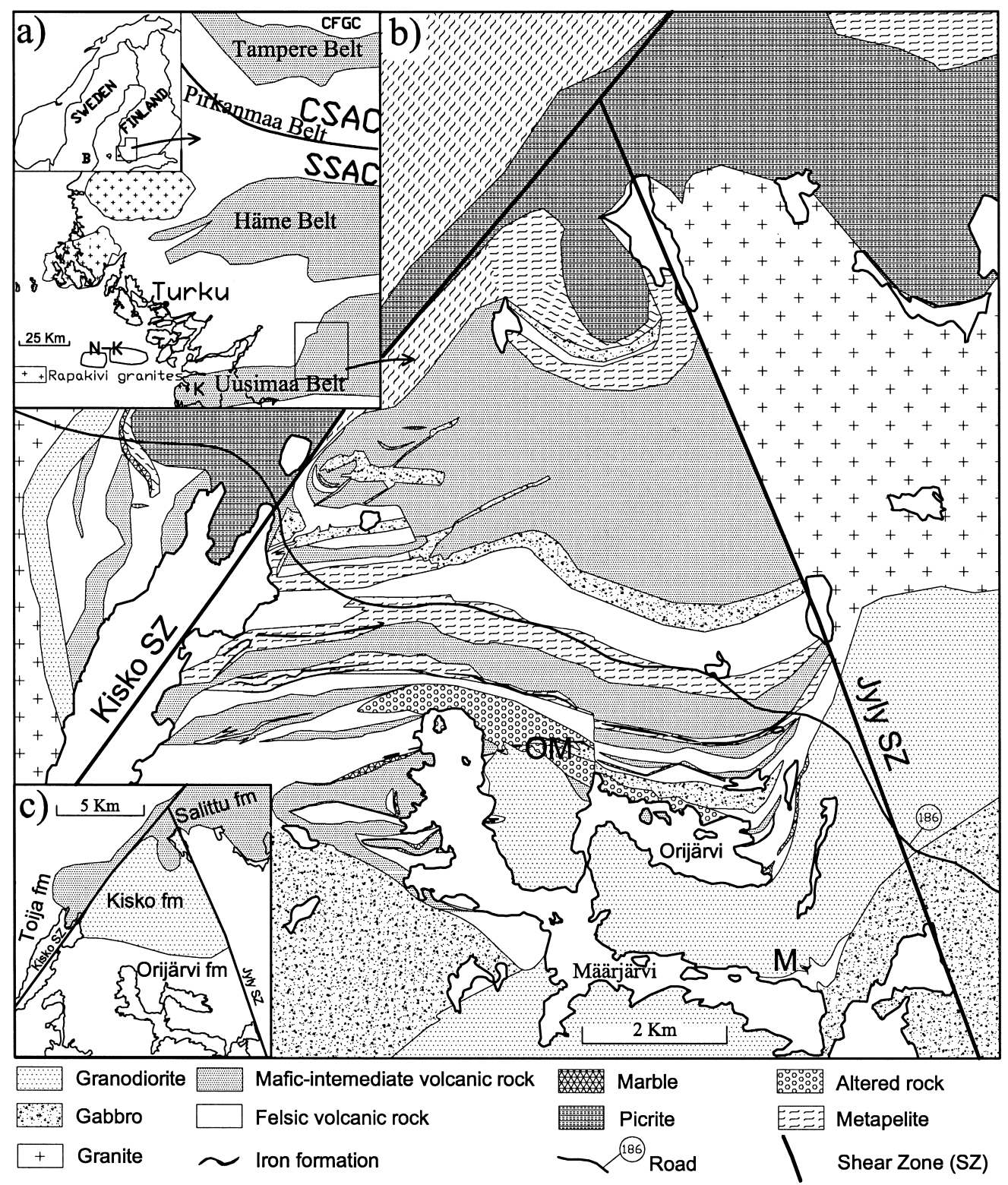

Fig. 1. Geological map of the Orijärvi area, modified after Härme (1958), Koistinen (1992) and Ploegsma and Westra (1990). B=Bergslagen, CFGC=Central Finland Granitoid Complex, CSAC=Central Svecofennian Arc Complex, $K=$ Kemiö, $N$-K=Nagu-Korpo, M=Malmberget, OM=Orijärvi Mine, SSAC=Southern Svecofennian Arc Complex. 1a) shows the main features of the bedrock in $S W$ Finland, 1b) is a lithological map of the study area, and 1c) outlines the four formations in the study area.

lack of essential trace elements that are needed for interpretation of tectonic settings of different rock types.

The purpose of this study is (i) to map the Orijärvi area in sufficient detail in order to identify all the main formations and interpret their age relationships, (ii) to study major and trace element geochemistry of the unaltered igneous rocks from each formation, (iii) to date the volcanic rocks with the conventional U-Pb method, and (iv) on the 
basis of obtained data to interpret the tectonic setting of the volcanic rocks in the Orijärvi area and to discuss the regional implications of the data.

\section{GEOLOGICAL SETTING}

\section{Regional geology}

The Orijärvi area belongs to a roughly east-west trending volcanic-sedimentary belt comprising felsic and mafic volcanic and sedimentary rocks that are intruded by $1.91-1.88$ Ga synvolcanic, 1.88$1.86 \mathrm{Ga}$ synorogenic and 1.84-1.81 Ga late-orogenic igneous rocks (Huhma 1986, Suominen 1991, Ehlers et al. 1993, Väisänen et al. 2000, Väisänen et al. 2002). In addition, ca. $1.80 \mathrm{Ga}$ post-orogenic and ca. $1.60 \mathrm{Ga}$ anorogenic plutonic rocks occur close to the belt (Vaasjoki 1977, Eklund et al. 1998). This belt, called the Uusimaa Belt, is bounded to the north and south by abundant late-orogenic granites and migmatites. Another volcanic belt, the Häme Belt, is situated to the north, but to the south the bedrock is hidden beneath the Gulf of Finland. These volcanic-sedimentary systems form the SSAC (Fig. 1a). Complex deformation and high metamorphic temperatures make it difficult to follow the lithological units within the SSAC and hamper interpretations of their age relationships. The Orijärvi area makes an exception to this, since a part of the area, known as the Orijärvi triangle, is only moderately strained and in places preserves primary depositional structures. Besides this, metamorphic temperatures were not high enough for anatexis (Ploegsma \& Westra 1990). Therefore, the area (Fig. 1b) is ideal for a study on the stratigraphy and geochemistry of volcanic rocks of the SSAC.

\section{Local geology}

During the field work the lithology and field relationships between different rock types were emphasized. Basic structural observations, e.g. mapping of depositional way-up structures and bedding-cleavage relationships were also carried out in order to identify the major fold structures important for interpretations of stratigraphy. On the basis of lithology, field relationships, geochemistry and radiometric age determinations, the area is subdivided into four formations: the Orijärvi formation, the Kisko formation, the Salittu formation, and the Toija formation (Figs. $1 \mathrm{~b}$ and 1c).

The Orijärvi formation (Orijärvi fm) is exposed in an upright antiform containing the Orijärvi granodiorite (and its more mafic varieties) in its core. Rocks surrounding the Orijärvi granodiorite show intensive hydrothermal alteration and host exhausted $\mathrm{Cu}-\mathrm{Zn}-\mathrm{Pb}$ mineralizations (Latvalahti 1979). Outside the alteration zones the formation comprises alternating mafic and felsic flows (Fig. 2a) and interlayers of marbles and iron formations. Pillowed lavas and sedimentary intercalations, including a volcanic conglomerate, indicate a subaqueous environment. The Orijärvi fm is interpreted to be the lowermost unit in the stratigraphy, and according to Colley \& Westra (1987) and Väisänen et al. (2002) the Orijärvi granodiorite is coeval with the volcanic rocks. Mafic dykes and quartz porphyries are also included in this formation.

The Kisko formation (Kisko fm), exposed in an upright synform to the north of the Orijärvi fm, is inferred to lie stratigraphically above the latter. A zone of greywackes and andalusite- and cordierite-bearing mica schists occurs between these formations. Detrital zircons in these greywackes are older than the under- and overlying volcanic rocks (Claesson et al. 1993 and this study). The rock types range from mafic to felsic tuffs and flows including intermediate varieties. They locally show primary sedimentary structures such as graded bedding, load casts and erosional bases that indicate a subaqueous environment (Fig. 2b). In the upper part of the volcanic pile occur minor felsic fragmental flows (Fig. 2c) and an ultramafic interlayer. The volcanic-sedimentary rocks are intruded by gabbros and plagioclase porphyries that show both concordant and discordant contact relationships to the adjacent supracrustal rocks.

The Salittu formation (Salittu fm) overlies the Kisko Fm from which it is conformably separated by, in places andalusite-bearing, metapelite 
(Fig. 2d). The Salittu fm comprises mainly ultramafic and mafic lavas (Schreurs et al. 1986), which are occasionally brecciated (Fig. 2e) and pillowed (Fig. 2f and $2 \mathrm{~g}$ ) and have interbeds of metapelite (in part slightly graphite bearing) and minor marbles. The volcanic rocks are intruded by gabbros and rare plagioclase-rich dykes (Fig. 2h). To the north of the Salittu fm ultramafic-mafic rocks are apparently overlain by garnet-cordierite mica gneisses. The axial planes of later folds are injected by garnet- and cordierite-bearing anatectic leucosome.

The Toija formation (Toija fm) is situated west of a prominent shear zone, the Kisko Shear Zone, and is overlain by pillowed lavas of the Salittu fm. It consists of mafic (pillowed) and felsic volcanic rocks intercalated with marbles and K-feldsparand sillimanite-bearing metapelites intruded by tonalites-diorites. An ultramafic horizon occurs close to the contact to the Salittu fm, but field relationships do not reveal whether it is a dyke or a lava flow.

Structurally and metamorphically, the Orijärvi and Kisko formations resemble each other showing early upright structures weakly refolded by later deformations in temperatures below anatexis. The Salittu and Toija formations are dominated by early gently dipping structures (folds and foliations) refolded by later upright folds, and migmatites are common. The correlation of structures across the formations follows that presented by Ploegsma and Westra (1990).

\section{GEOCHEMISTRY}

Igneous rocks from each formation described above were sampled for major and trace element analyses. The samples were analysed at Activation Laboratories Ltd., Ontario, Canada. Major elements and $\mathrm{Ba}, \mathrm{Ni}, \mathrm{Sr}, \mathrm{Y}$, and $\mathrm{Zr}$ were analysed by inductively coupled plasma emission (ICP), REEs and Ce, Cr, Hf, Ta and Th by instrumental neutron activation analysis (INAA), and $\mathrm{Nb}$ and $\mathrm{Rb}$ by X-ray fluorescence (XRF). The results are presented in Table 1 and the sample sites are shown in Appendix 1.

\section{Major elements}

Major element geochemistry is presented in the form of total alkali vs. silica plot (TAS; Fig. 3) and major element oxides vs. silica (Harker) diagrams (Fig. 4). The purpose of using the TAS diagram is merely demonstrative since at least some alkali/silica mobility may be suspected as indicated by the analyses that plot outside the igneous spectrum of Hughes (1973; Fig. 5). However, because the collected samples were apparently the freshest and least altered in the study area, the TAS diagram (Fig. 3) approximately shows the main igneous rock types. The classification of the samples as tholeiitic vs. calc-alkaline depends on the diagram used because AFM and $\mathrm{FeO} * / \mathrm{MgO}$ vs. $\mathrm{SiO}_{2}$ diagrams mostly give conflicting results and they do not show clear trends; only the samples from the Salittu fm show a clear tholeiitic trend (figures not shown). The volcanic rocks in Fig. 3 are simplified to picrites (>12\% MgO; Le Bas 2000), mafic volcanic rocks and felsic volcanic rocks.

\section{The Orijärvi formation}

The volcanic rocks from the Orijärvi fm plot in medium-K basalt/basaltic andesite and dacite/rhyolite fields. Therefore, a marked bimodality is demonstrated in the analyses since no samples plot in andesite field. The $\mathrm{TiO}_{2}$ contents in the mafic rocks are lower $(0.4-0.8 \mathrm{wt} \%)$ than in the other formations, but the $\mathrm{Al}_{2} \mathrm{O}_{3}$ contents are generally slightly higher (Fig. 4). The samples with the highest $\mathrm{Al}_{2} \mathrm{O}_{3}$ contents might have accumulated plagioclase. The contents of $\mathrm{Fe}_{2} \mathrm{O}_{3}, \mathrm{CaO}$ and $\mathrm{P}_{2} \mathrm{O}_{5}$ are not in general different from the other formations. The $\mathrm{K}_{2} \mathrm{O}$ contents are lower than in the Kisko fm, but are roughly the same as in the Salittu and Toija formations. Sample ORM-17 from a low stratigraphic level shows the highest $\mathrm{MgO}$ content (ca. $13 \mathrm{wt} \%$, Table 1) and is actually a picrite. In all plots of Fig. 4, the gabbro and the subvolcanic mafic dyke plot among the mafic volcanic rocks and the Orijärvi granodiorite plots close to the felsic volcanic rocks. 

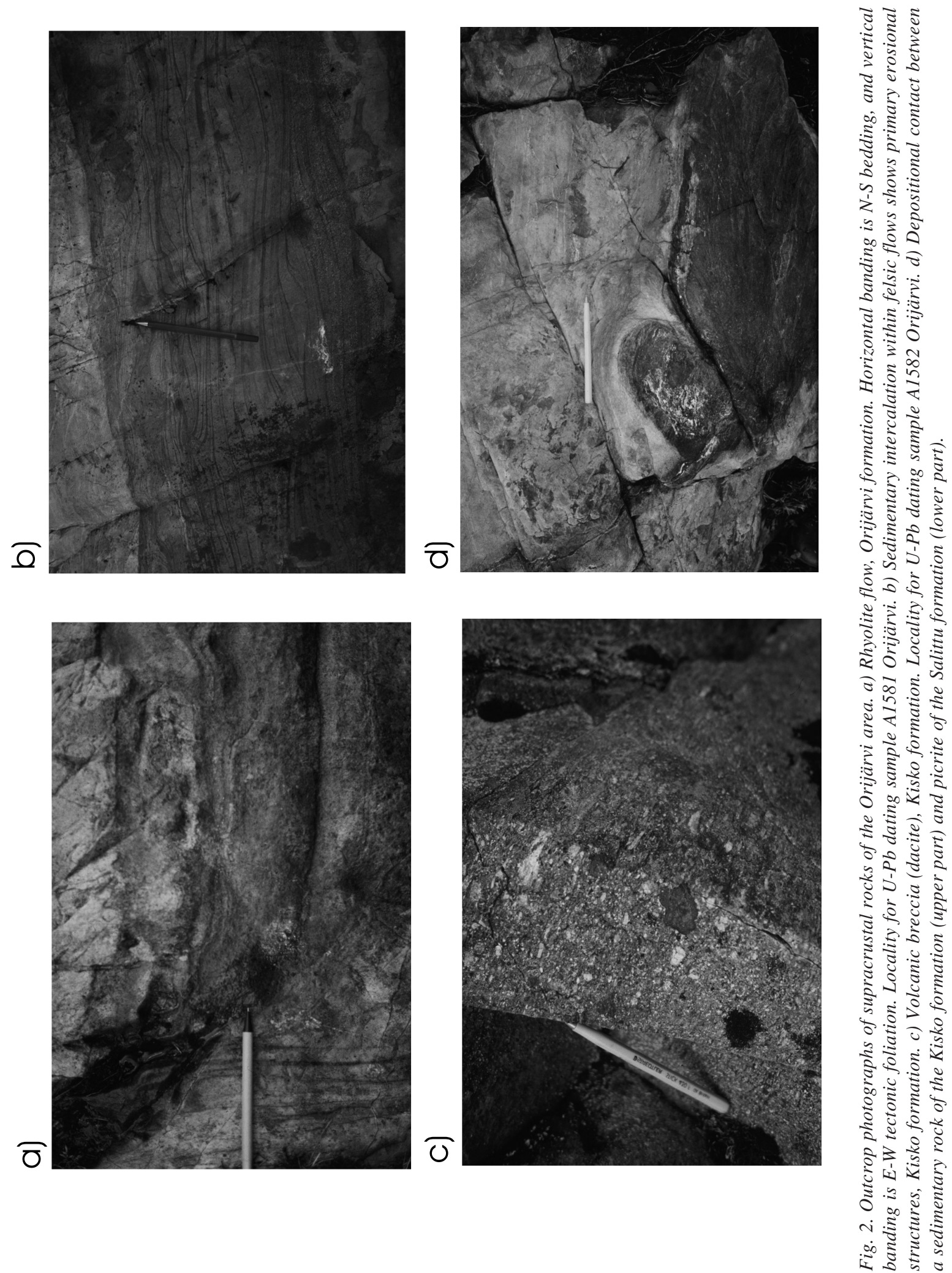

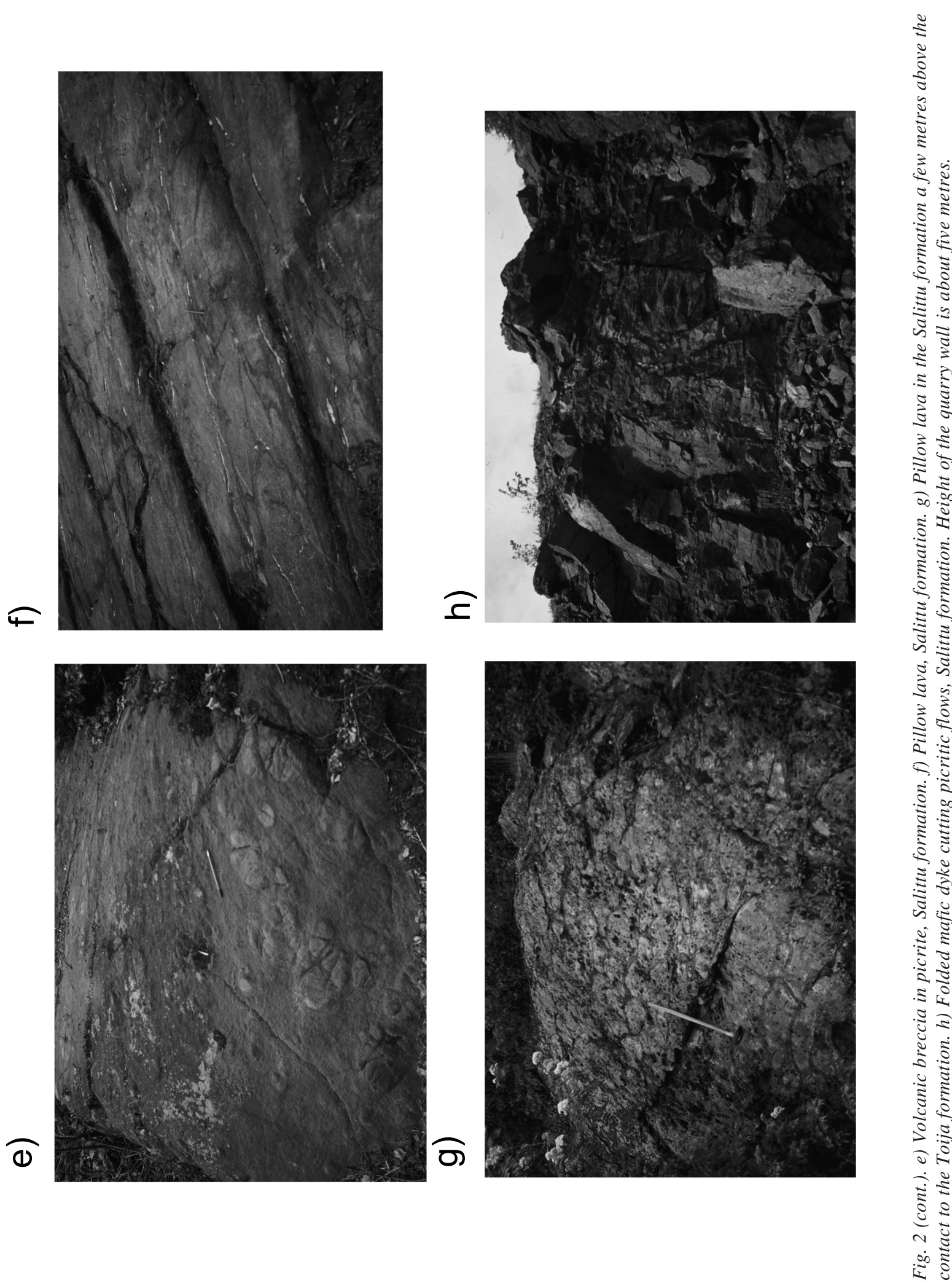


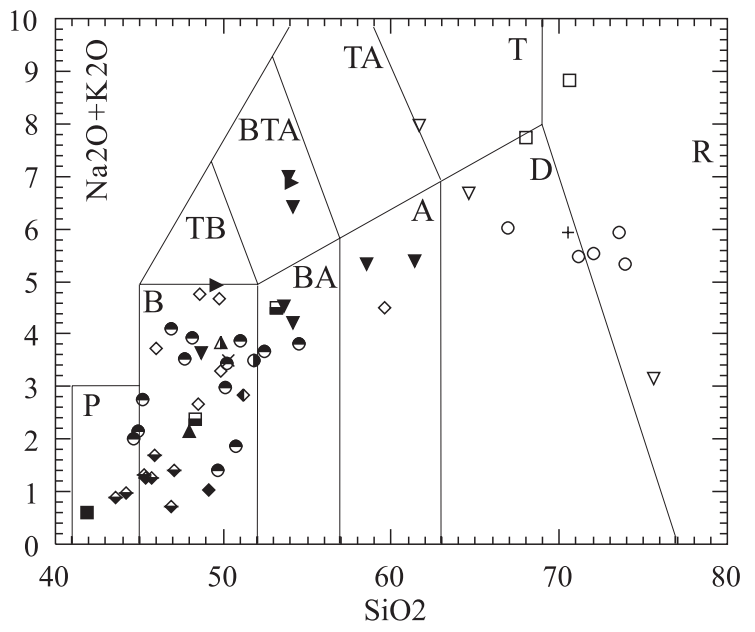

- Orijärvi fm, mafic volcanic

- Orijärvi fm, felsic volcanic

- Orijärvi fm, mafic dyke

+ Orijärvi fm, granodiorite

$\times$ Orijärvi fm, gabbro

$\nabla$ Kisko fm, mafic volcanic

- Kisko fm, pl-porphyry

- Kisko fm, picrite

$\nabla$ Kisko fm, felsic volcanic

\section{The Kisko formation}

The main feature of the Kisko fm is its generally high contents of alkalis and that the mafic-intermediate volcanic rocks plot in medium- to highK fields (Fig. 4). In the TAS diagram (Fig. 3) the analyses scatter from basalt to rhyolite with no pronounced bimodality and some analyses plot in trachytic fields. The $\mathrm{TiO}_{2}$ contents are generally higher than in the Orijärvi fm but roughly the same as in the other formations. Other major elements are roughly like those in the Orijärvi and the Toija formations. The coarse-grained gabbro plots within the basalt field among the Kisko fm volcanic rocks. A picritic (16 wt $\% \mathrm{MgO}$ ) interlayer containing felsic fragments was found high up in the stratigraphy of the Kisko fm. Another specific feature is two plagioclase-porphyry samples that display very high $\mathrm{P}_{2} \mathrm{O}_{5}$ values ( 0.76 and $1.12 \mathrm{wt} \%$ ). These are interpreted as volcanic dykes.

\section{The Salittu formation}

The Salittu fm is characterized by ultramafic picritic volcanic rocks that are intercalated with ma-
Fig. 3. Total alkali vs. silica (TAS) diagram. Fields after Le Maitre (1989): $P=$ Picrobasalt, $B=$ Basalt, $B A=$ Basaltic andesite, $A=$ Andesite, $D=$ Dacite, $B T A=$ Basaltic trachyandesite, $T A=$ Trachyandesite, $T=$ Trachyte, $R=$ Rhyolite.

fic pillow lavas. The picrites and mafic lavas both plot in low- to medium-K fields (Fig. 4). The rocks show higher $\mathrm{TiO}_{2}$ and lower $\mathrm{Al}_{2} \mathrm{O}_{3}$ contents than the other formations and, consequently, low $\mathrm{Al}_{2} \mathrm{O}_{3} /$ $\mathrm{TiO}_{2}$ ratios. The picrites have, naturally, high $\mathrm{MgO}$ contents. Alkali contents in picrites are low, but in basalts clearly higher. Low alkali and $\mathrm{Al}_{2} \mathrm{O}_{3}$ contents in the picrites suggest that these rocks contained minor or no original plagioclase (see Leybourne et al. 1997). As shown in Fig. 5, many of the samples in this formation plot outside the igneous spectrum suggesting alkali mobilisation, maybe due to sea-floor hydrothermal alteration. The gabbro sample does not plot among the volcanic rocks of this formation. A plagioclase-rich dyke cutting the picrites shows low alkali and high $\mathrm{P}_{2} \mathrm{O}_{5}(0.46 \mathrm{wt} \%)$ contents.

\section{The Toija formation}

Mafic volcanic rocks from the Toija fm are medium-K basalts and basaltic andesites. In Fig. 5 both samples plot outside the igneous spectrum. 

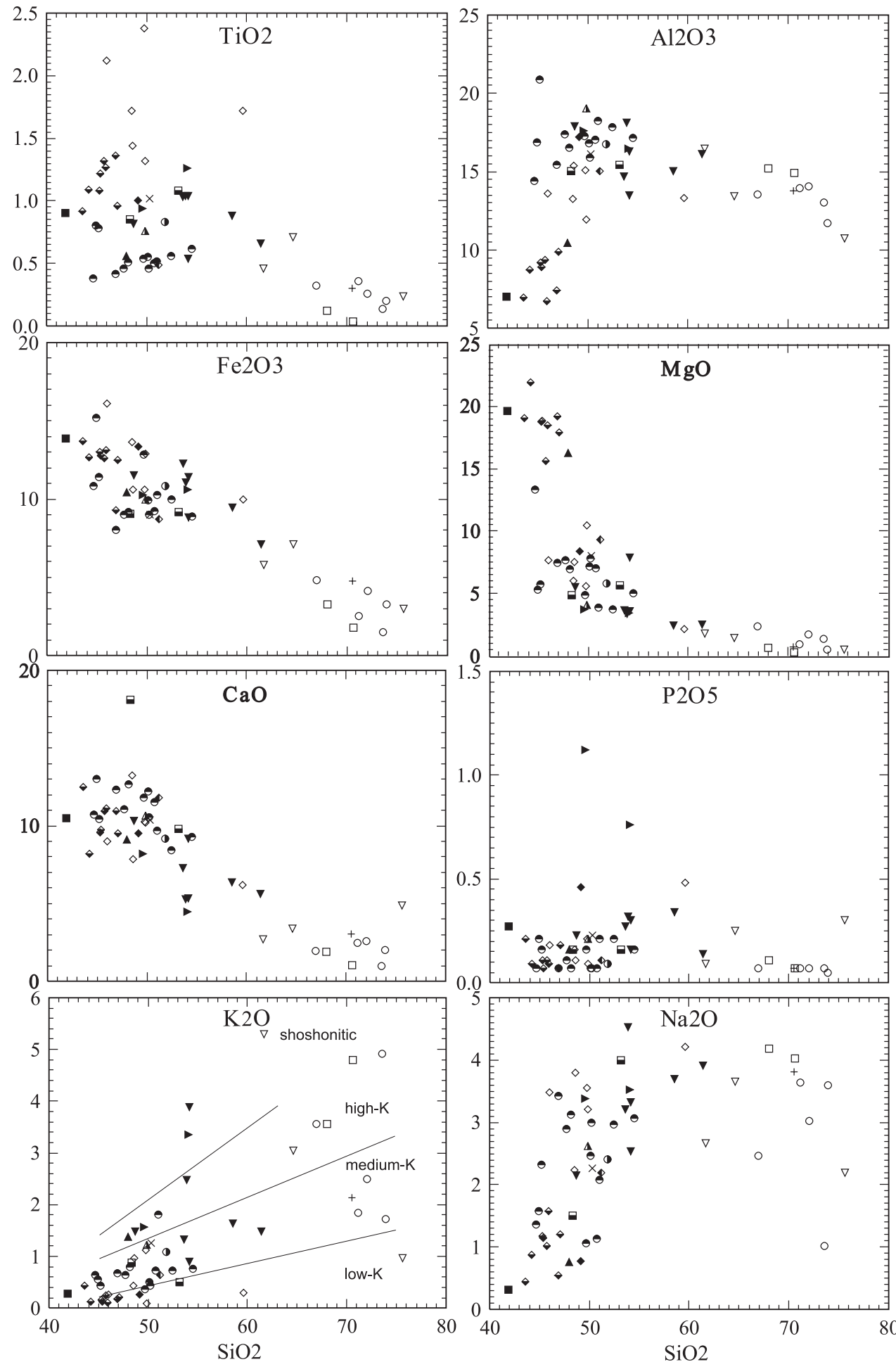

Fig. 4. Major elements vs. silica (wt\%) diagrams. Symbols as in Fig. 3. The fields in the $\mathrm{SiO}_{2} v \mathrm{~s} . \mathrm{K}_{2} \mathrm{O}$ diagram after Middlemost (1985). 


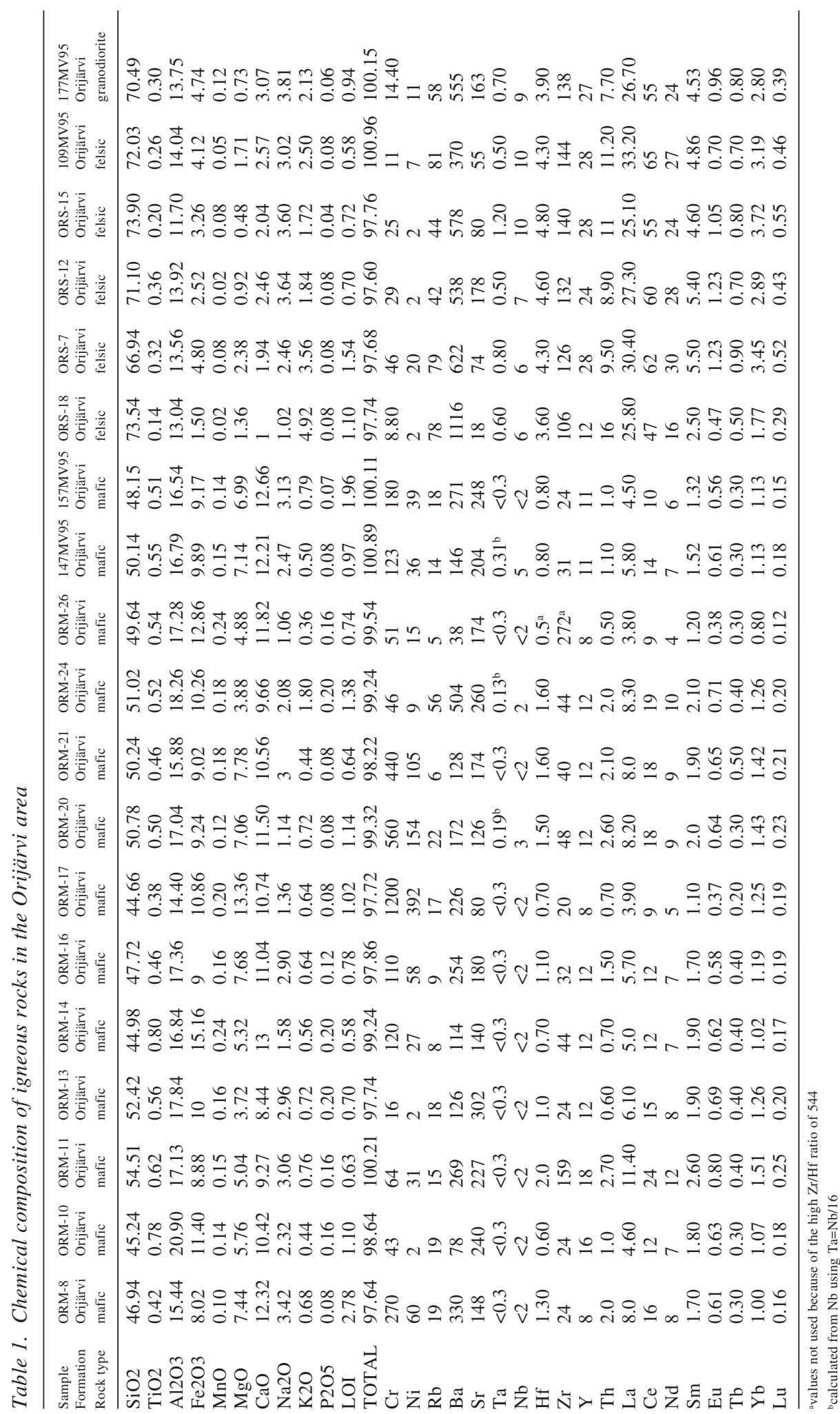




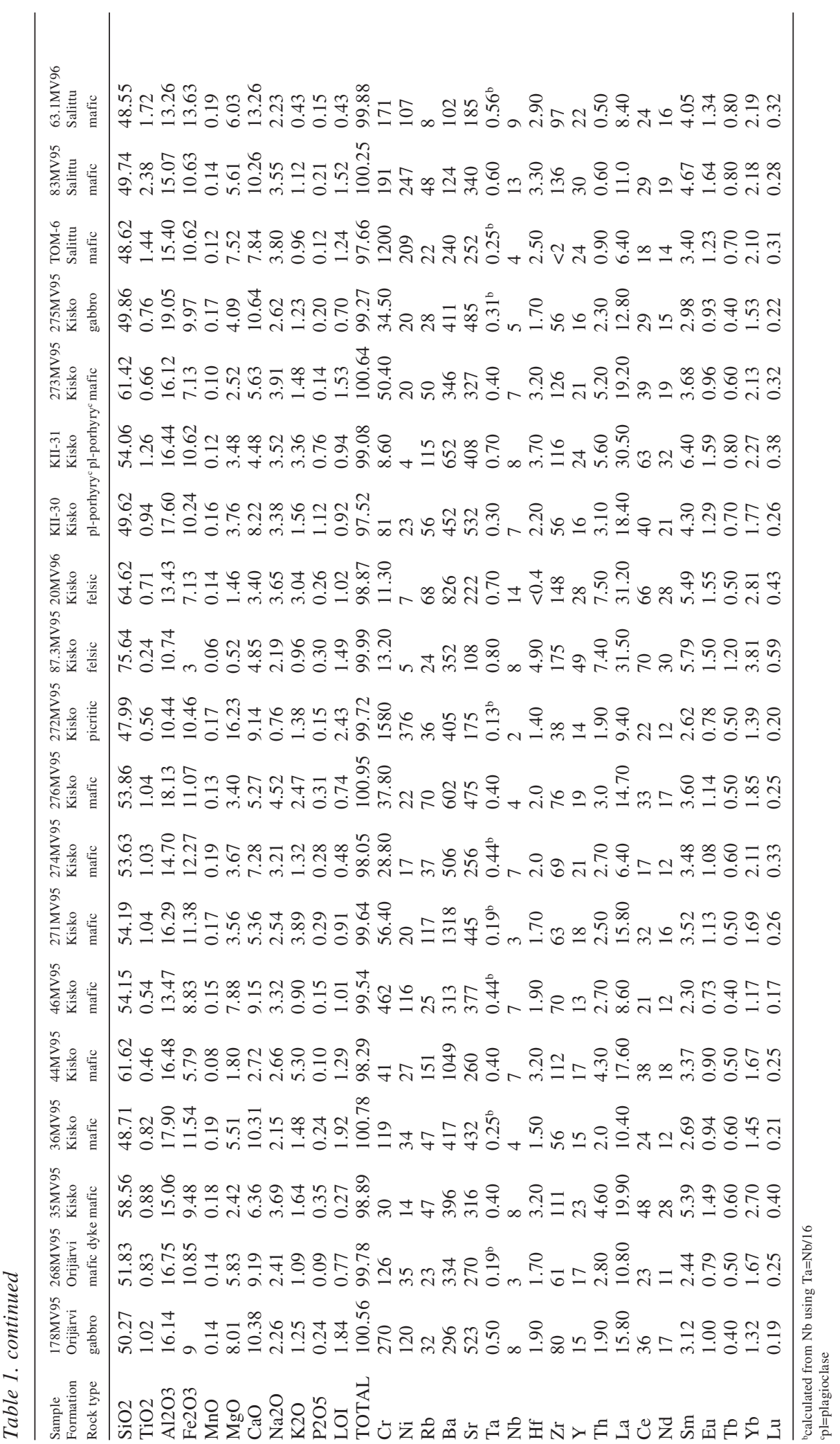




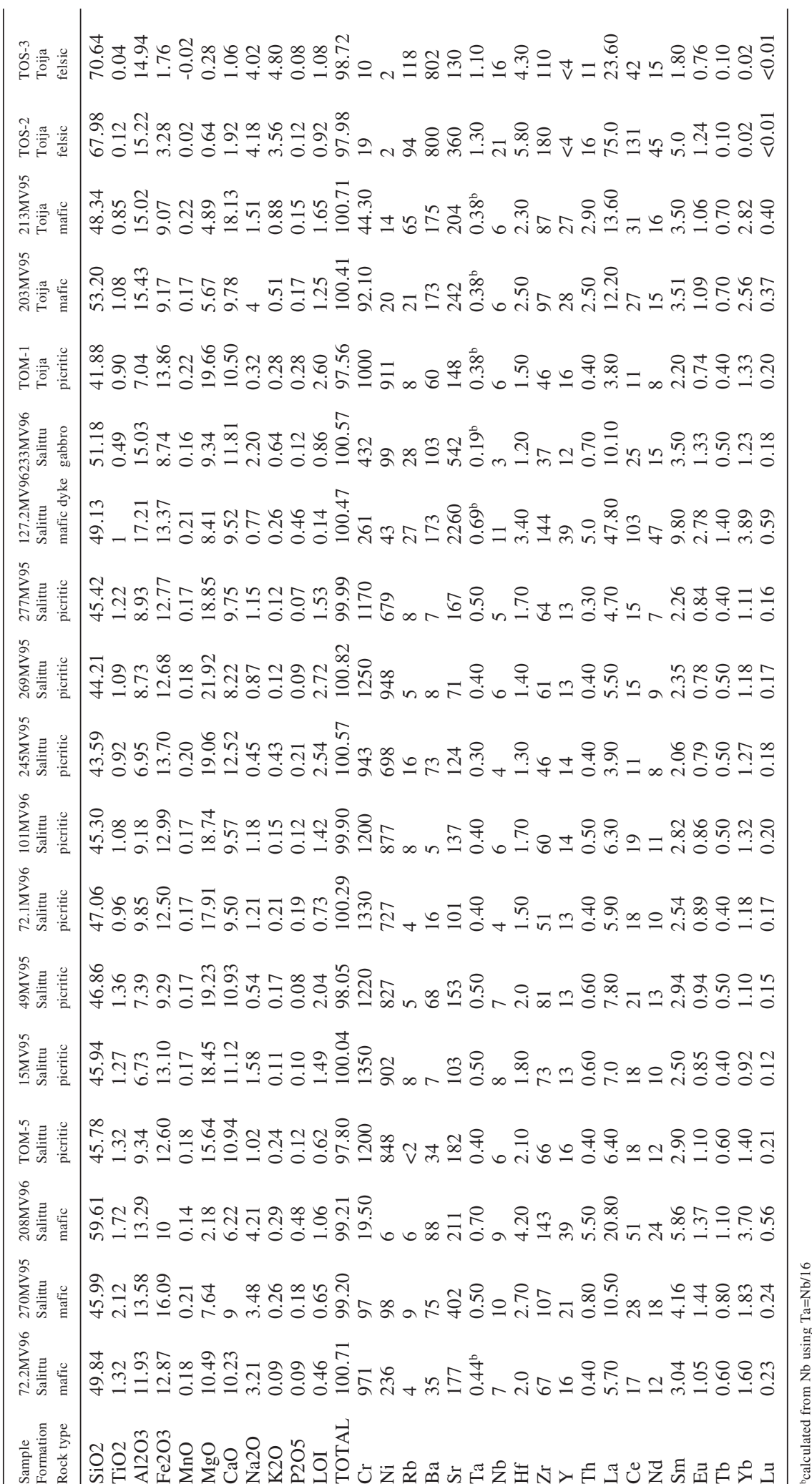




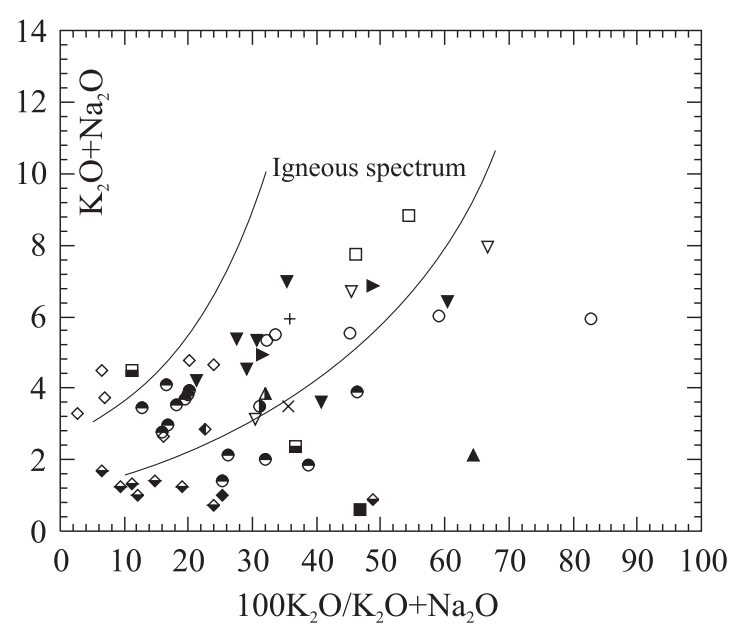

Fig. 5. Alkali alteration diagram after Hughes (1973). Symbols as in Fig. 3.

The $\mathrm{TiO}_{2}$ contents are intermediate between those of the Orijärvi and Salittu formations and the $\mathrm{Fe}_{2} \mathrm{O}_{3}$ contents are rather low. One of the analyses shows $\mathrm{Ca}$ content higher than the other suggesting mobility of calcium. Other major elements plot within the same fields as the other formations. The felsic volcanic rocks in this formation contain slightly lower $\mathrm{TiO}_{2}, \mathrm{MgO}$ and slightly higher $\mathrm{Na}_{2} \mathrm{O}$ and $\mathrm{Al}_{2} \mathrm{O}_{3}$ compared to felsic rocks in the other formations. The picritic intercalation or dyke, close to the contact to the Salittu fm in the northern part of the Toija fm, shows low $\mathrm{SiO}_{2}$ (ca. $42 \mathrm{wt} \%$ ) and high $\mathrm{MgO}$ (ca. $20 \mathrm{wt} \%$ ) content.

\section{Minor and trace elements}

Minor and trace elements are presented in the form of various trace element plots, including $\mathrm{N}$ MORB-normalized multielement diagrams and chondrite-normalized REE diagrams. Some elements, in particular $\mathrm{Nb}$ and $\mathrm{Ta}$ in the Orijärvi fm, are close to or below the detection limit in many of the samples. This hampers their use in detailed discussion. However, that information is still useful in a more general discussion since even when an analysis is below the detection limit, it indicates a very low element content. Therefore, in the analyses where the contents of $\mathrm{Nb}$ or $\mathrm{Ta}$ are below the detection limits, we have used the detection limit values in diagrams. The abbreviations used in the text are high field strength element (HFSE), large ion lithophile element (LILE), rare earth element (REE), light rare earth element (LREE), and heavy rare earth element (HREE).

\section{The Orijärvi formation}

Four mafic samples (ORM-8, ORM-17, ORM-20, ORM-21, Table 1) from the lower part of the Orijärvi fm show the highest contents of Ni (60-393 ppm) and Cr (270-1200 ppm), and low Zr, Y and Ti values. Combined with the highest $\mathrm{MgO}$ contents in this formation (Figs. 4 and 6), these rocks resemble island arc tholeiites (e.g. Stern et al. 1995a). The samples highest in $\mathrm{Ni}$ and $\mathrm{Cr}$ can be regarded as primitive arc magmas (see Smith et al. 1997). The $\mathrm{Ni}$ and $\mathrm{Cr}$ contents decrease upwards in the volcanic pile suggesting that the magmas get more evolved.

Based on the N-MORB-normalized multielement diagram (Fig. 7a) it is evident that $\mathrm{K}, \mathrm{Rb}$, $\mathrm{Ba}$, Th, and to a minor extent Ce (LILEs) are strongly enriched over the HFSEs $\mathrm{Nb}, \mathrm{Zr}$, Hf, and Ti which plot below the typical N-MORB composition. Niobium and occasionally $\mathrm{Zr}$ show minor negative troughs (except one sample). These kinds of patterns are typical for subduction-related volcanic rocks and are often taken to indicate a subduction component (e.g. Pearce 1983, Pearce 1996, Macdonald et al. 2000). Chondrite-normalized REE diagram patterns (Fig. 7b) show a gentle negative slope with La values 15 to 50 times chondrite and $\mathrm{Yb}$ values 4 to 10 times chondrite.

\section{The Kisko formation}

The Ni and Cr contents of the Kisko fm are generally low, $<35 \mathrm{ppm} \mathrm{Ni}$ and $<119 \mathrm{Cr}$, except one sample with 116 ppm Ni and 462 ppm Cr (Fig. 6). The multielement diagram patterns (Fig. 7c) resemble those of the Orijärvi fm, but the overall element abundances are generally higher, especially for the LILEs. Normalized $\mathrm{Zr}$ and Hf contents are elevated compared to the Ti contents. The REE patterns (Fig. 7d) are also similar to those of the Orijärvi fm, but the element abundances are higher. The La contents are 25 to 90 times chondrite 

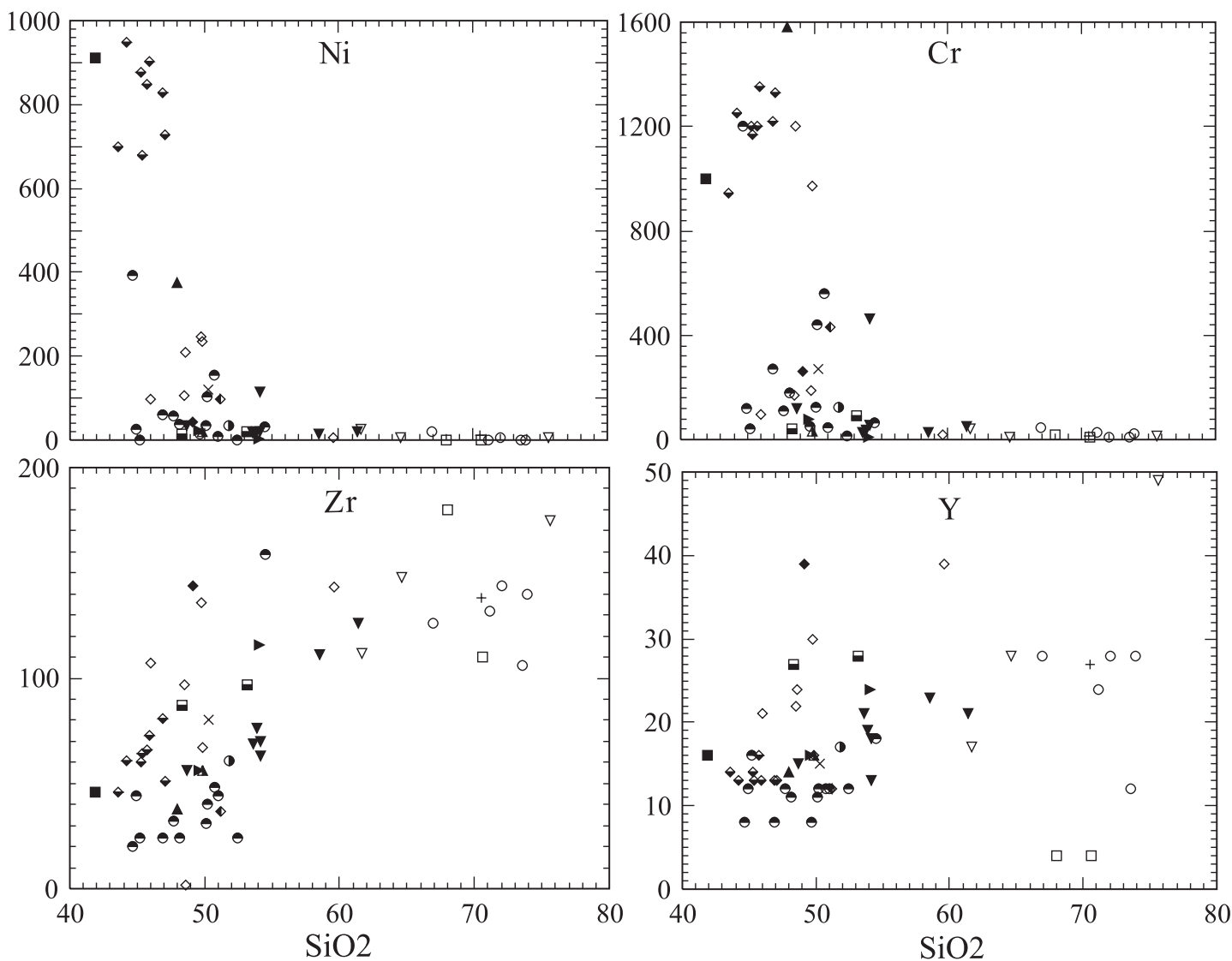

Fig. 6. Selected minor and trace element (ppm) vs. silica (wt\%) diagrams. Symbols as in Fig. 3.

and $\mathrm{Yb}$ values 7 to 17 times chondrite. The normalized diagrams show quite enriched trace element patterns, and combined with major element data, the formation displays an evolved or mature volcanic arc with a pronounced subduction component signature. The picritic interlayer (Figs. 8a and $8 b$ ) shows high LILE/HFSE ratios.

\section{The Salittu formation}

The Ni and $\mathrm{Cr}$ contents of the volcanic rocks of the Salittu fm are usually higher than in the other formations. In picrites, of course, they are strongly elevated (400-950 ppm Ni and 900-1600 ppm Cr, Fig. 6). The high $\mathrm{Mg}$ contents together with the high $\mathrm{Ni}$ and $\mathrm{Cr}$ contents suggest that the rocks may represent primary magmas (e.g. Macdonald et al. 2000). The multielement diagrams (Figs. 8a and 8c) show slightly elevated LILE and HFSE contents close to (in picrites, Fig. 8a) or slightly higher (in basalts, Fig. 8c) than in MORB. The diagrams do not show any negative $\mathrm{Nb}$ (Ta), $\mathrm{Zr}$, or $\mathrm{Ti}$ anomalies, i.e. there is no evident subduction component. Many samples display elevated $\mathrm{Rb}$ and $\mathrm{Ba}$ contents. The REE patterns show slight enrichments in LREE (Figs. 8b and 8d).

\section{The Toija formation}

The multielement diagram patterns for the pillow basalts of the Toija fm show features that are transitional between the Orijärvi/Kisko fms and the Salittu fm (Fig. 7e). LILEs are enriched in a similar way as in the Orijärvi/Kisko fms, but HFSEs mostly follow the MORB pattern thus resembling the patterns of the Salittu basalts. Slight negative 

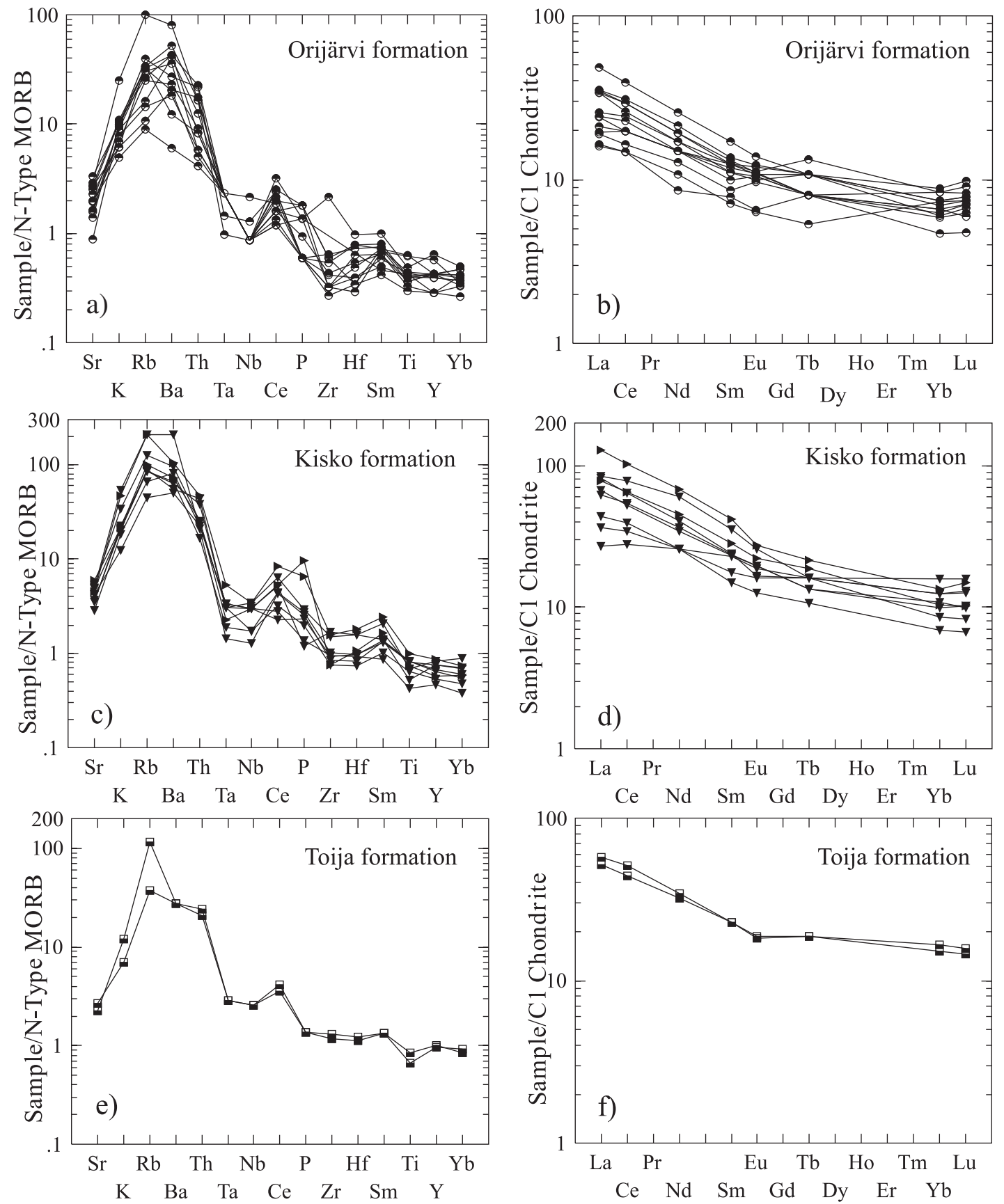

Fig. 7. N-MORB-normalized multielement and chondrite-normalized REE diagrams of the mafic volcanic rocks from the Orijärvi, Kisko and Toija formations. Normalizing values from Sun and McDonough (1989), element order from Pearce (1983). In a) the contents of Ta and $\mathrm{Nb}$ based on the detection limit values of (0.3 and 2 ppm, respectively) are displayed with open circles. Other symbols as in Fig. 3. 

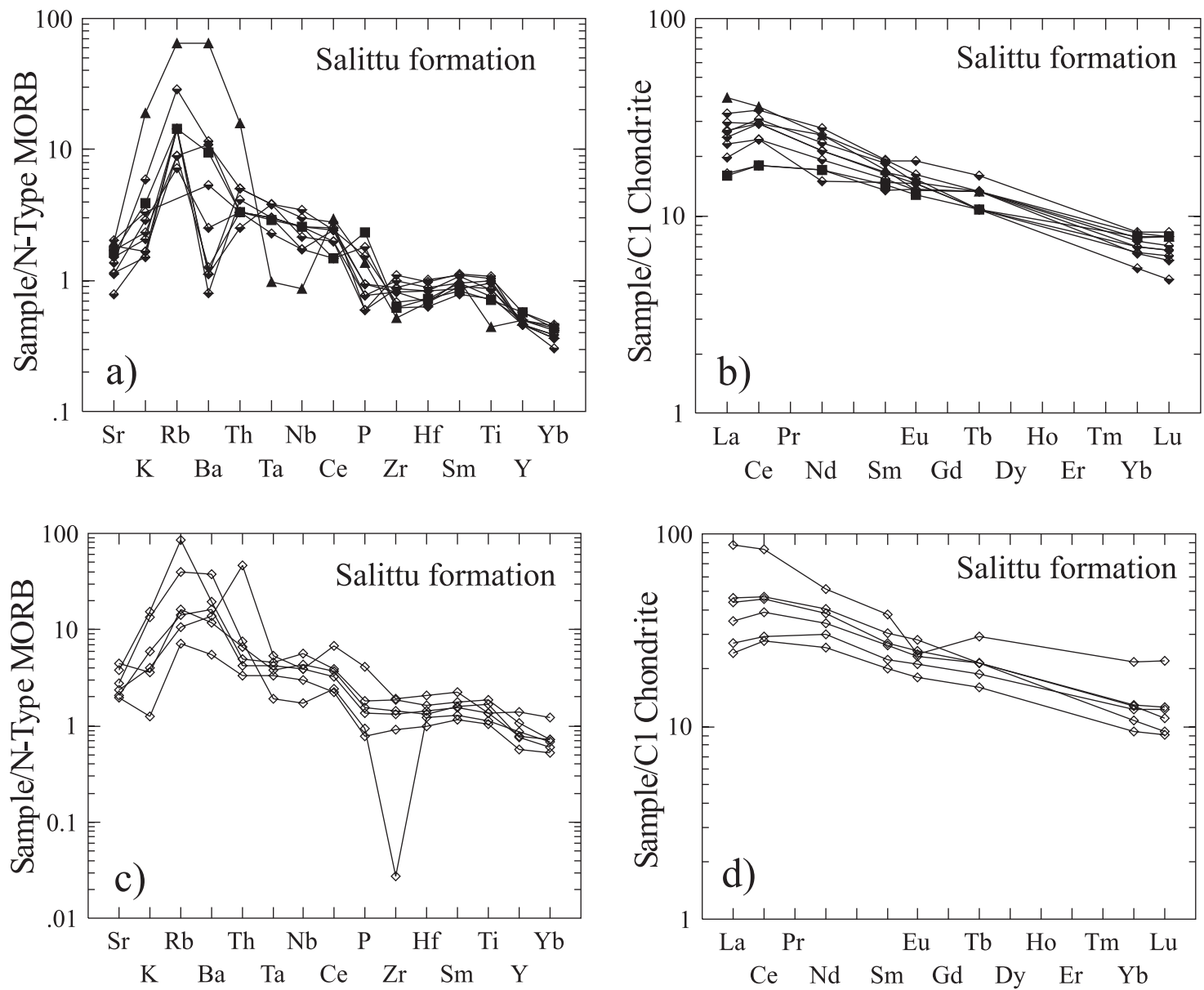

Fig. 8. N-MORB-normalized multielement and chondrite-normalized REE diagrams of the a-b) picritic and c-d) basaltic volcanic rocks from the Salittu formation. Diagrams a) and b) also include picrites from the Kisko formation (filled triangle) and the Toija formation (filled square). Sample 208MV96 in c) with high REE contents is andesitic with $59.61 \mathrm{wt} \% \mathrm{SiO}_{2}$. Normalizing values from Sun and McDonough (1989), element order from Pearce (1983). Symbols as in Fig. 3.

$\mathrm{Nb}$ and $\mathrm{Ti}$ anomalies indicate a subduction component. The REE patterns (Fig. 7f) show elevated LREE contents similar to the pattern of the Kisko fm. The picritic layer (or dyke) resembles the picrites of the overlying Salittu fm (Figs. 8a and $8 \mathrm{~b}$ ).

\section{Felsic volcanic rocks}

The main feature of the felsic volcanic rocks (rhyolites and dacites, Fig. 3) is their high LILE/HFSE ratios as demonstrated by high $\mathrm{Th}$ (and $\mathrm{Ce}$ ) and low Ti (and P) values in multielement normalized patterns (Fig. 9). The Orijärvi fm in general has slightly lower overall contents of the elements compared to the Kisko fm. The Toija fm shows the highest LILE contents, high $\mathrm{Zr}$ and very pronounced negative Ti and Y anomalies. The characteristic feature of the Toija $\mathrm{fm}$ is the strong LREE enrichment together with extremely depleted HREEs ( $\mathrm{Lu}$ under detection limit) creating a strongly negative slope. The Toija fm also shows a slight positive Eu anomaly, contrary to the felsic volcanic rocks from the other formations. 

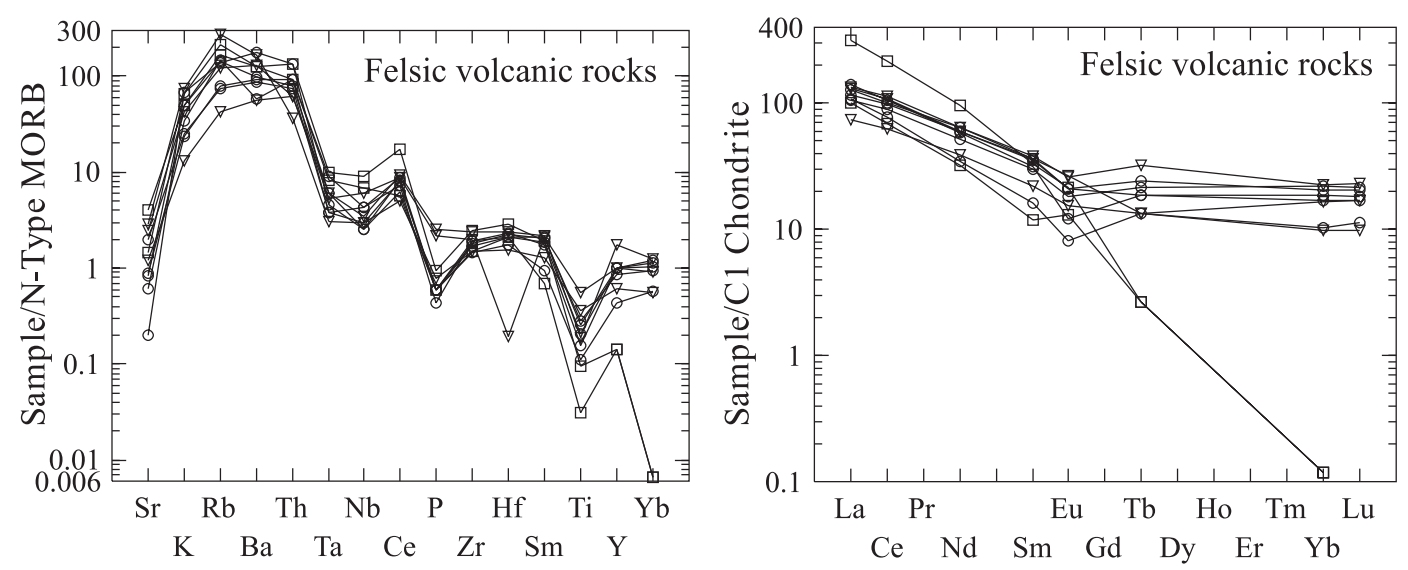

Fig. 9. N-MORB-normalized multielement and chondrite-normalized REE diagrams of felsic volcanic rocks from the Orijärvi area. Normalizing values from Sun and McDonough (1989), element order from Pearce (1983). Symbols as in Fig. 3.

\section{Intrusive rocks}

All the four formations contain rocks with intrusive field relationships to adjacent rocks or show other plutonic features. Some of them were sampled for geochemistry.

The geochemical composition of the Orijärvi granodiorite, dated at $1898 \pm 9 \mathrm{Ma}$ by ion microprobe (Väisänen et al. 2002), is similar to the composition of the felsic volcanic rocks in the Orijärvi $\mathrm{fm}$, trace element composition in particular. When the data are plotted together in a multielement diagram, they nicely overlap each other (Fig. 10). Therefore, the granodiorite and felsic volcanic rocks are regarded comagmatic.

The gabbroic mafic part of the intrusion (sample 178MV95) shows the closest similarities with the more evolved volcanic rocks of the Orijärvi $\mathrm{fm}$ and less evolved rocks of the Kisko fm. Therefore, the least differentiated volcanic rocks at the lowest stratigraphic levels are derived from a magma chamber that is not exposed or sampled in the study area. The mafic dyke, interpreted to be synvolcanic (Latvalahti 1979, sample 268MV95), has a chemical composition roughly similar to both the volcanic rocks and the gabbro supporting the synvolcanic origin. The chemical composition of the gabbro dyke in the Kisko fm (sample 275MV95) cannot be distinguished from the gabbro of the
Orijärvi fm described above. These three mafic intrusive rocks have similar patterns in multielement and REE diagrams (Fig. 11) and, consequently, a mutual genesis is indicated.

The gabbro from the Salittu fm (sample 233MV96) is different in chemical composition compared to the other intrusive rocks. The multi-

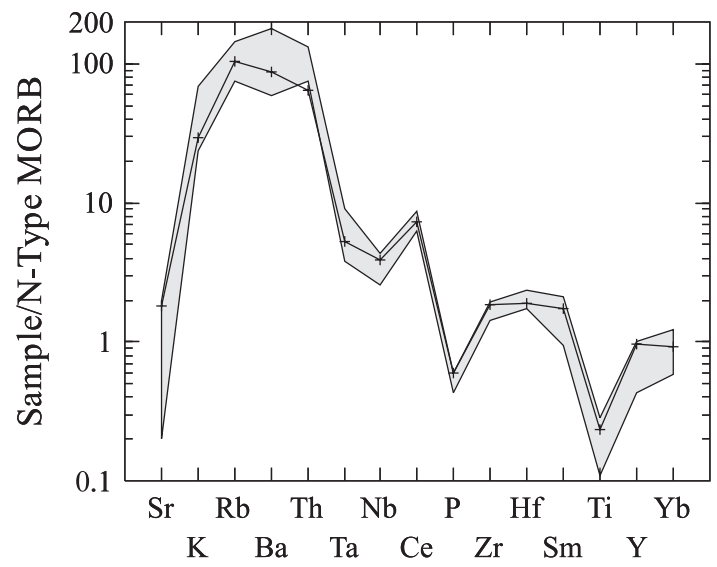

Fig. 10. N-MORB-normalized multielement diagram of the Orijärvi granodiorite (line with crosses) compared with the felsic volcanic rocks from the Orijärvi formation (grey shade). 

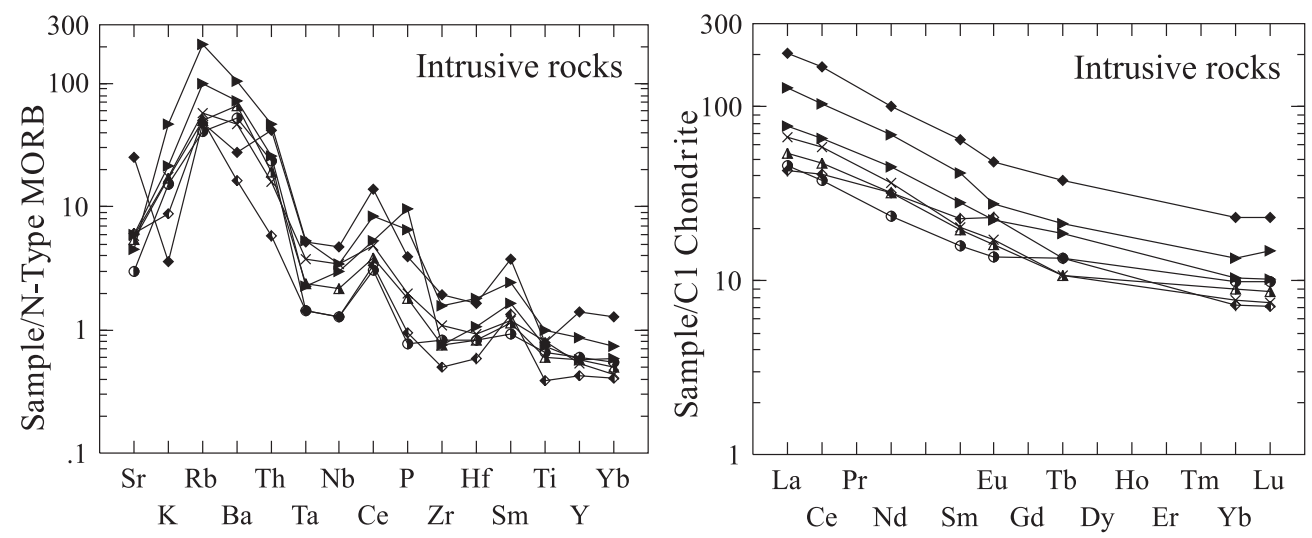

Fig. 11. N-MORB-normalized multielement and chondrite-normalized REE diagrams of intrusive rocks from the Orijärvi area. Normalizing values from Sun and McDonough (1989), element order from Pearce (1983). Symbols as in Fig. 3.

element diagram (Fig. 11) shows lower $\mathrm{Sr} / \mathrm{K}$ and higher $\mathrm{Rb} / \mathrm{Ba}$ ratios, and the abundances of $\mathrm{Th}, \mathrm{Ce}$, $\mathrm{Nb}, \mathrm{Ta}, \mathrm{Zr}$ and $\mathrm{Hf}$ are low. Niobium and Ti show negative and Sm positive anomalies. The REE diagram (Fig. 11) shows a moderate negative slope with a weak positive Eu anomaly. The important point is that the gabbro also is geochemically different compared to the surrounding volcanic rocks of the Salittu fm. It displays a high LILE/HFSE ratio and negative troughs of $\mathrm{Zr}$ and $\mathrm{Ti}$ that are typical of subduction-related rocks.

The plagioclase-rich mafic dyke in the Salittu fm cross-cuts the volcanic rocks but has been folded. The dyke is enriched in incompatible elements, especially in Sr (2260 ppm) and REEs (Fig. 11), but the total alkalis are low (1.0 wt \%, Fig. 3). Therefore, the dyke is not of shoshonitic or oceanic-island basalt type.

The plagioclase-porphyry samples from the Kisko Fm are strongly enriched in LILE (and P, for major elements, see Fig. 4) and show high REE abundances. In this respect, they slightly resemble the enriched dyke in the Salittu fm.

All the intrusive rocks plot in the volcanic arc field in the $\mathrm{Rb}$ vs. $\mathrm{Y}+\mathrm{Nb}$ diagram (Fig. 12). Although independent field evidence and age data are required to definitely correlate the intrusive rocks with a synvolcanic or synorogenic stage, geochemical composition of these rocks indicates a volcanic rather than synorogenic stage.

\section{U-PB AGE DETERMINATIONS}

In order to constrain the time brackets for the volcanic activity in the study area, two felsic volcanic rock samples from the Orijärvi and Kisko formations were collected for $\mathrm{U}-\mathrm{Pb}$ age determinations. From the Salittu fm, we did not find suitable volcanic rock types for $\mathrm{U}-\mathrm{Pb}$ age determination and the Toija fm was not sampled. The sampling localities are shown in Appendix 1.

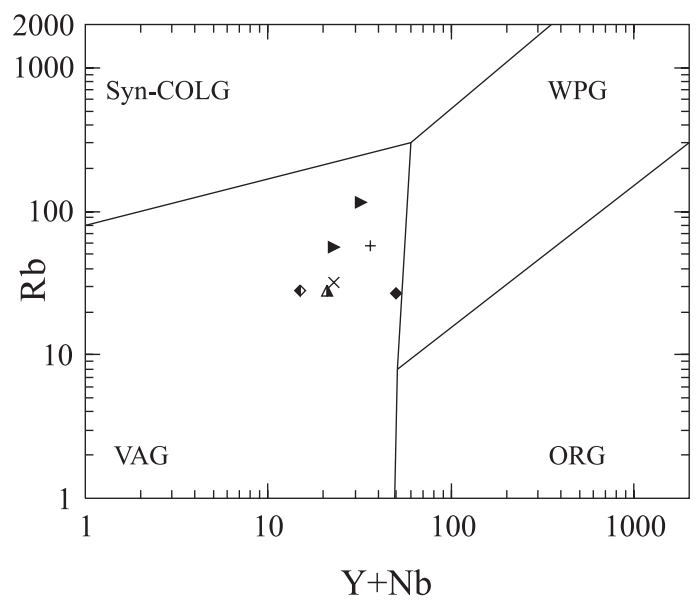

Fig. 12. $Y+N b$ vs. Rb diagram after Pearce et al. (1984). ORG=Ocean Ridge Granites; Syn-COLG=Syn-Collisional Granites; VAG=Volcanic Arc Granites; $W P G=$ Within Plate Granites. Symbols as in Fig. 3. 


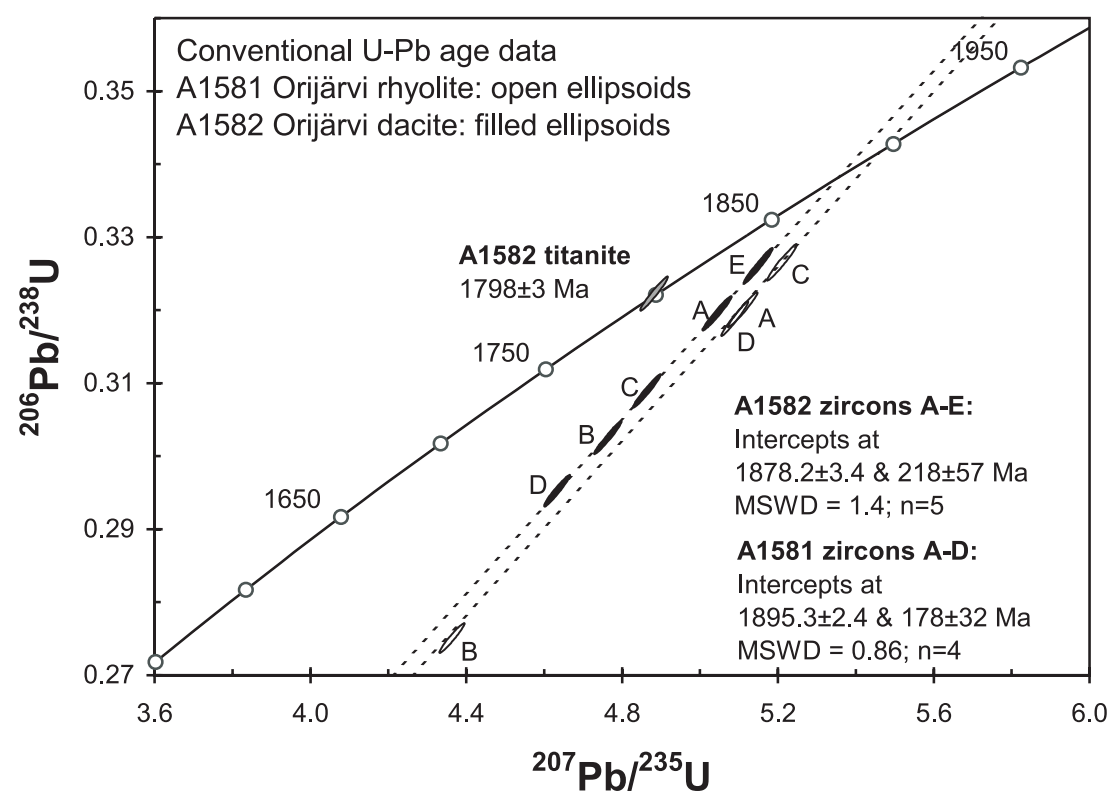

Fig. 13. Concordia plot for the $U-P b$ data.

\section{Analytical methods}

The decomposition of zircons and titanites, and extraction of $\mathrm{U}$ and $\mathrm{Pb}$ for conventional isotopic age determinations follows principally the procedure described by Krogh (1973). ${ }^{235} \mathrm{U}-{ }^{208} \mathrm{~Pb}$-spiked and non-spiked isotopic ratios were measured using a VG Sector 54 thermal ionization multicollector mass spectrometer. The measured lead and uranium isotopic ratios were normalized to the accepted ratios of the SRM 981 and U500 standards. The U-Pb age calculations were done using the PbDat-program (Ludwig 1991) and the fitting of the discordia lines using the Isoplot/Ex program (Ludwig 1998).

\section{A1581 Orijärvi}

Zircons recovered from the rhyolite sample A1581 from the Orijärvi formation are mainly light brown, translucent, and prismatic with length to width ratios of ca. 2 to 3 . Occasionally these zircons contain brown inclusions and more turbid inner domains. All the four analysed zircon fractions (Table 2) plot well on the same discordia line giving an upper intercept age of $1895.3 \pm 2.4 \mathrm{Ma}$ and a lower intercept age of $178 \pm 32$
(MSWD=0.86; n=4; Fig. 13). The upper intercept age is considered to constrain the time of the volcanism in low stratigraphic levels in the Orijärvi area.

\section{A1582 Orijärvi}

For U-Pb dating, a small amount of zircons and large amount of dark brown titanites were recovered from the dacite sample A1582 from the Kisko formation. Compared to zircons from the rhyolite sample, zircon population from the dacite seems to be more heterogeneous. The colour of typical zircons varies from almost colourless to brownish, and inclusions are common. In addition, one broken crystal with a darker brown inner domain was detected.

Five analysed zircon fractions (Table 2) define a discordia line which intercepts the concordia curve at $1878.2 \pm 3.4 \mathrm{Ma}$ and $218 \pm 57 \mathrm{Ma}$ (MSWD=1.4; n=5; Fig. 13). The upper intercept age determines the age of the volcanism in high stratigraphic levels in the Orijärvi area.

The titanite fraction gives a concordant age of $1798 \pm 3$ Ma. 
Table 2. Conventional U-Pb zircon and titanite analyses from Orijärvi volcanic rocks. Samples A1581 Orijärvi rhyolite and A1582 Orijärvi dacite.

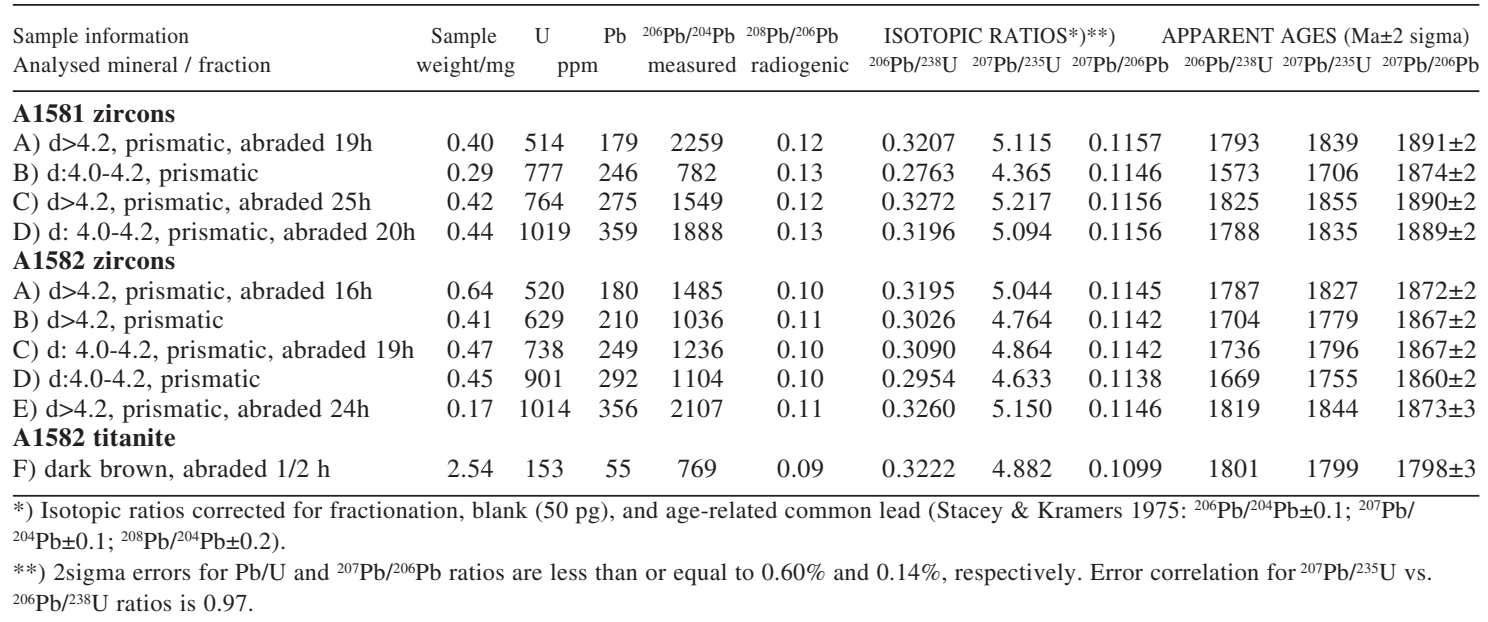

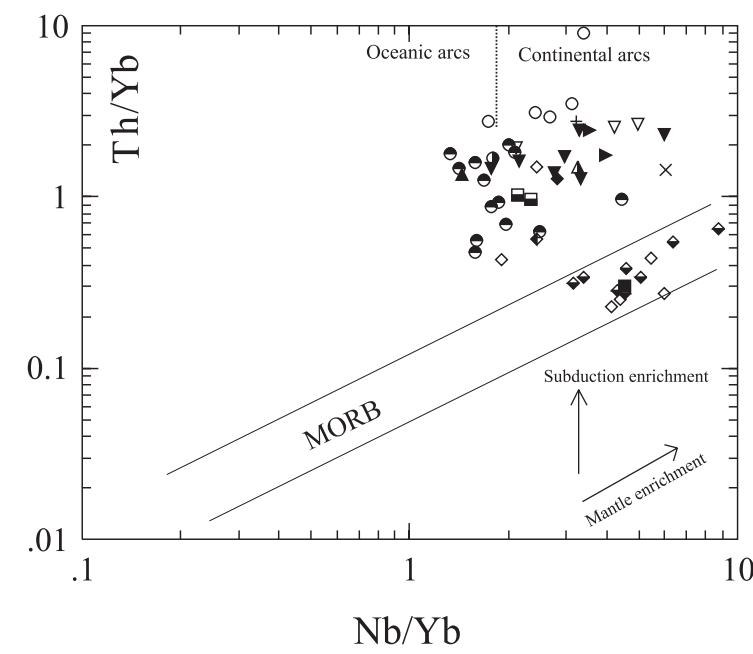

Fig. 14. Nb/Yb vs. Th/Yb diagram after Pearce (1983) and Stern et al. (1995b). For the samples with $\mathrm{Nb}$ under the detection limit (2 ppm), a Nb value of 2 ppm was used. Symbols as in Fig. 3.

\section{DISCUSSION}

\section{Genesis of the igneous rocks}

Field investigations, geochemistry and radiometric age data reveal the existence of four different formations, which apparently do not share a com- mon origin, age and place of formation. Therefore, it is convenient first to discuss the genesis of the rocks separately for each formation.

\section{The Orijärvi formation}

The volcanic rocks of the lowermost (i.e. oldest) Orijärvi fm show a pronounced bimodal silica distribution. The mafic rocks are characterized by low $\mathrm{Ti}, \mathrm{Zr}, \mathrm{Hf}, \mathrm{Nb}$, Ta, and $\mathrm{Y}$ contents while e.g. Th is enriched with respect to N-type MORB. Moderate to high $\mathrm{Ni}$ and $\mathrm{Cr}$ contents at the lowest stratigraphic levels are also noticed. These geochemical features make these rocks similar to those found in modern subduction-related environments, and the basalts at the lowest levels resemble basalts of oceanic arc systems. This is demonstrated in the $\mathrm{Nb} / \mathrm{Yb}$ vs. $\mathrm{Th} / \mathrm{Yb}$ diagram (Fig. 14) where all the igneous rocks of the Orijärvi fm plot above the MORB-array indicating a subduction-related enrichment process. An interpretation that volcanism started in an oceanic arc setting but evolved into a continental arc volcanism is only tentative since the $\mathrm{Nb}$ contents are below the detection limit in most mafic samples of the Orijärvi $\mathrm{fm}$. In the Hf-Nb-Th diagram these rocks, includ- 


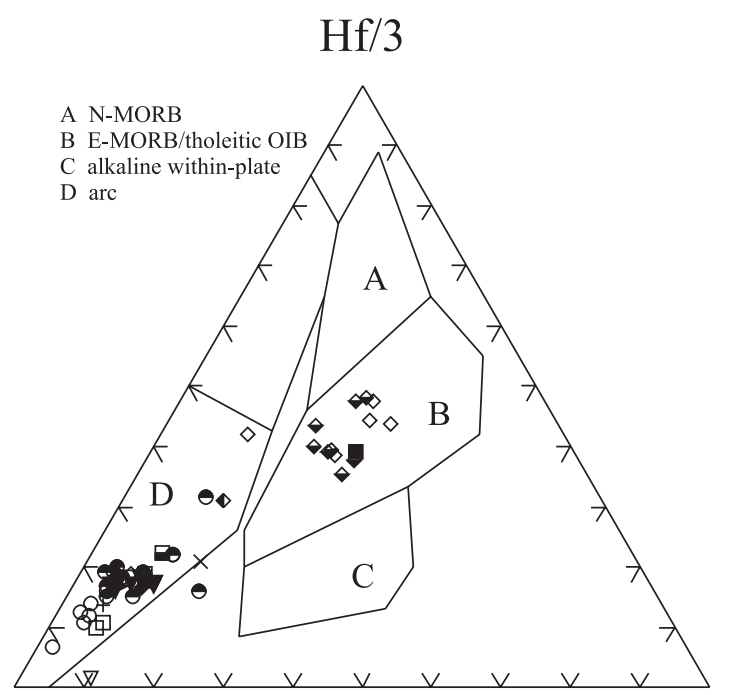

$\mathrm{Th}$

$\mathrm{Nb} / 16$

Fig. 15. Hf-Nb-Th diagram after Wood (1980). For the samples with $\mathrm{Nb}$ under the detection limit (2 ppm), a $\mathrm{Nb}$ value of 2 ppm was used. Symbols as in Fig. 3.

ing the felsic ones, plot within the arc field (Fig. 15). The problem with this scenario is the bimodality of volcanism, i.e. where were the felsic rocks derived from? In general, felsic volcanic rocks in arc settings can be attributed to differentiation of mafic rocks, melting of pre-existing crust or a mixture of these. Unfortunately, these questions need isotope data to be answered and this is outside the scope of this study. However, Huhma (1986) studied the Orijärvi granodiorite and obtained an $\varepsilon_{\mathrm{Nd}}(1.89 \mathrm{Ga})$ value of -0.7 . Because it is argued in this study that the volcanic rocks are comagmatic with the intrusive rocks, also the felsic volcanic rocks should show $\varepsilon_{\mathrm{Nd}}$ values close to zero. Negative $\varepsilon_{\mathrm{Nd}}$ values at $1.89 \mathrm{Ga}$ indicate incorporation of an older crustal component, either Archaean or older Proterozoic (perhaps ca. 2.0 Ga, see Lahtinen \& Huhma 1997), but they do not discriminate between melting of the underlying crust and sediment subduction (cf. Huhma 1986, Nironen 1997). Although Väisänen et al. (2002) did not find older zircons from the Orijärvi granodiorite in an ion microprobe study, we suggest that the mafic volcanic rocks were generated from juve- nile mantle sources and the felsic rocks, at least partly, were generated from an older crustal component.

\section{The Kisko formation}

Many ancient and modern volcanic arcs show an evolution from early primitive, often tholeiitic volcanism to later more evolved, often calc-alkaline volcanism (e.g. Leybourne et al. 1997). Evolution in geochemistry was also observed in this study. The volcanic rocks of the Kisko fm are enriched in alkalis and LILEs, some individual samples even plot in the high-K and shoshonitic fields in the $\mathrm{K}_{2} \mathrm{O}$ vs. $\mathrm{SiO}_{2}$ diagram (Fig. 4). The silica contents do not show a bimodal distribution as in the underlying Orijärvi fm, because andesitic rocks are present. The patterns in the N-MORB-normalized multielement diagrams resemble those of the Orijärvi fm, apart from higher element abundances. In the $\mathrm{Nb} / \mathrm{Yb}$ vs. Th/Yb (Fig. 14), Hf-Nb-Th (Fig. 15), and $\mathrm{Nb} / \mathrm{Y}$ vs. Th/Nb (Fig. 16) diagrams, analyses from the Kisko fm plot together with samples from the Orijärvi fm indicating a subduction-related setting and volcanic arc affinities.

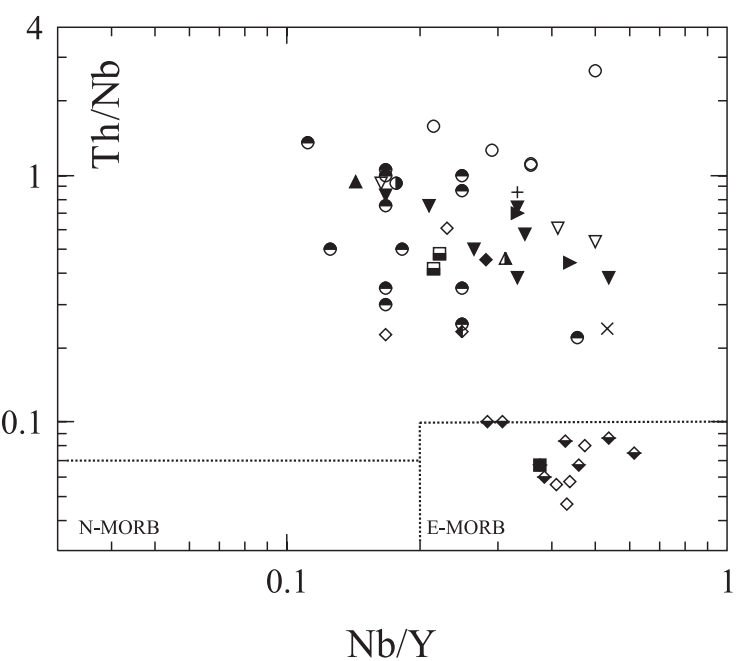

Fig. 16. $N b / Y$ vs. Th/Nb diagram after Stern et al. (1995b). For the samples with Nb under the detection limit (2 ppm), a Nb value of 2 ppm was used. Symbols as in Fig. 3. 
Compared to the Orijärvi fm, the chemical composition of the rocks from the Kisko fm manifests a thicker crust and possibly crustal contamination as indicated by higher $\mathrm{Rb} / \mathrm{Ba}$ ratios (Figs. $7 \mathrm{a}$ and $8 \mathrm{a})$. Therefore, they can be regarded as mature volcanic arc rocks.

The phosphorus-rich plagioclase-porphyritic dykes are strongly enriched in LILEs and LREEs. They might represent a later stage of still more evolved magmatism. Related volcanic rocks were, however, not found.

\section{The Salittu formation}

Major element contents of basalts and picrites in the Salittu fm are different from the arc-type Orijärvi and Kisko formations in their higher Ti and $\mathrm{Mg}$ contents and lower $\mathrm{Al}$ and alkali contents. Further, lower Th and higher $\mathrm{Zr}$ contents than in the underlying arc-related formations are characteristic. These features resemble those of oceanfloor- or within-plate-related rather than arc-related volcanic rocks. Ocean-floor affinities are displayed in the diagrams that use incompatible traceelement ratios. In the Hf-Nb-Th diagram the Salittu samples plot in the E-MORB field whereas the samples from the other formations plot in the arc field (Fig. 15). The Th/Nb ratio is a useful incompatible element ratio because Th is highly enriched in continental crust and the melts passing through such a crust should show elevated $\mathrm{Th} / \mathrm{Nb}$ ratios if contaminated (Stern et al. 1995b). In the $\mathrm{Nb} / \mathrm{Y}$ vs. $\mathrm{Th} / \mathrm{Nb}$ diagram (Fig. 16) the Salittu basalts and picrites plot within the E-MORB field $(\mathrm{Th} / \mathrm{Nb}<$ 0.1 , with the exception of few samples that by field evidence are suspected to be contaminated. This indicates that most of the samples from the E-MORB-type Salittu formation do not show crustal contamination and the chemical compositions of the rocks reflect enriched mantle composition. This is also evident in the $\mathrm{Nb} / \mathrm{Yb}$ vs. $\mathrm{Th} / \mathrm{Yb}$ diagram (Fig. 14) where these samples plot within the MORB-array showing mantle enrichment with no obvious subduction-related contribution. The $\varepsilon_{\mathrm{Nd}}$ $(1.89 \mathrm{Ga})$ value of +3.1 (Huhma 1986) from a Salittu picrite (then called peridotite) points to a juvenile source. Pearce and Peate (1995) suggest that during arc rifting, new, fertile mantle can invade the mantle wedge causing enrichment only a short time before eruption. This process might explain the voluminous ultramafic (picritic) volcanism in the Salittu formation and the $\varepsilon_{\mathrm{Nd}}$ value of +3.1 in spite of the enriched mantle-type source.

Gabbro and mafic dyke from this formation have chemical compositions not comparable to surrounding volcanic rocks. Therefore, they are not regarded to represent original magma chambers of the basalts in the Salittu fm. The gabbro sample more resembles the intrusive rocks from the Orijärvi and Kisko formations. This suggests that a new stage of arc-type magmatism succeeded the E-MORB-type oceanic magmatism. The dyke is highly enriched in Sr and REEs, but depleted in alkalis, which is problematic to interpret. We propose that its chemical composition reflects contamination by some unknown material.

\section{The Toija formation}

The geochemical character of the pillow basalts in this bimodal formation is transitional between the arc-type Orijärvi and Kisko formations and the E-MORB-type Salittu fm as can be seen in many of the major element plots (Fig. 4). The patterns in the N-MORB-normalized diagram (Fig. 7) show a similarity to basalts of the Salittu fm, but the small $\mathrm{Nb}$ and $\mathrm{Ti}$ troughs and elevated $\mathrm{Th}$ values give a subduction signature that separates the Toija rocks from the Salittu rocks.

Felsic volcanic rocks of this formation are exceptional in their very low HREE contents and positive Eu anomalies not seen in felsic rocks from the other formations. This indicates a different source than e.g. for the rhyolites in the Orijärvi $\mathrm{fm}$, which show pronounced negative Eu anomalies (Fig. 9). The low HREE contents might indicate a deeper source of melting with garnet in the residue.

\section{Age data}

The U-Pb zircon age determinations presented here bracket the time span of volcanic activity in the Orijärvi area. The age of the rhyolite, 
1895.3 $\pm 2.4 \mathrm{Ma}$, from the Orijärvi formation is within errors the same as the $1898 \pm 9 \mathrm{Ma}$ ion microprobe age for the Orijärvi granodiorite in the core of the antiform (Väisänen et al. 2002). This supports the field observations that the Orijärvi fm is lowermost in stratigraphy and the idea that the granodiorite is comagmatic with the felsic volcanic rocks, which is supported by similar geochemistry. In the inferred continuation of the SSAC, the Bergslagen area in Sweden, volcanic rocks and coeval synvolcanic plutonic rocks are common (Allen et al. 1996).

The large uncertainties in the SIMS age and the possibility that the granodiorite has intruded older volcanic formations below the present surface, make it possible that volcanism started earlier than 1895 Ma. From Viholanniemi in southeastern Finland, Vaasjoki and Sakko (1988) dated a metarhyolite at $1906 \pm 4 \mathrm{Ma}$. It is, however, unclear if the locality is situated within the SSAC or the CSAC. Three other age determinations on volcanic rocks, $1887 \pm 14$ Ma from Pellinki in the Uusimaa Belt (Patchett \& Kouvo 1986), 1888 111 Ma from Kemiö in the Uusimaa Belt (Reinikainen 2001) and $1888 \pm 11$ Ma from Valijärvi in the Häme Belt (Vaasjoki 1994) have too large errors to precisely date their eruption ages. The oldest rhyolite in Bergslagen (Utö, Sweden) is dated at $1904 \pm 4 \mathrm{Ma}$ (Lundström et al. 1998). Therefore, we conclude that volcanism in the SSAC, at least in the Orijärvi area, started at ca. $1895 \mathrm{Ma}$ or earlier as indicated by the two slightly older ages outside this study area. Some of the intrusive rocks were cogenetic with the volcanic rocks. In the Tampere area within the CSAC the oldest dated volcanic rock has an age of 1904 \pm 4 Ma (Kähkönen et al. 1989, Kähkönen 1999).

The younger age at $1878 \mathrm{Ma}$ from the upper part of the Kisko fm confirms that volcanism lasted ca. 15 million years. However, as discussed above, the Salittu fm overlies the Kisko fm indicating a still younger period of volcanism. For comparison, in central Sweden volcanism as young as $1871 \pm 7 \mathrm{Ma}$ (Doppe et al. 1995) and $1867 \pm 9 \mathrm{Ma}$ (Welin 1987) has been dated. In southern Finland, synorogenic intrusions dated at ca. 1.87 Ga (Van Duin 1992, Nironen 1999, Väisänen et al. 2002) set the minimum age for volcanism. However, since the Salittu fm is interpreted to have emplaced in a back-arc basin, coeval volcanism in the evolving volcanic arc and back-arc ba$\sin$ is also possible. Therefore, the age of volcanism in the Salittu fm is unclear, but as discussed above, it cannot be much different from the age of the Kisko fm.

Comparing the ages in the Tampere and Orijärvi areas it is evident that volcanism is younger or continued longer in the south. The youngest volcanism in the Tampere area is dated at $1889 \pm 5 \mathrm{Ma}$ (Kähkönen et al. 1989) and by $1880 \mathrm{Ma}$ the area was already deformed, metamorphosed and intruded by synorogenic intrusions (Nironen 1989, Kilpeläinen 1998, Mouri et al. 1999). At the same time the volcanism was still active in the Orijärvi area. Collision-related deformation and magmatism in one area and coeval pre-collisional volcanism and sedimentation in an adjacent area cause a problem in correlation. Lahtinen (1996) proposed a suture zone north of the Häme Belt approximately along the Pirkanmaa Belt and concluded that the Tampere Belt and the Häme Belt originally formed on different plates that later collided and were stitched together. The idea of a suture zone possibly accounts for the apparent diachronism between the two areas. This also means that structures cannot be directly correlated between these areas. Väisänen et al. (2002) suggested that collision of these two plates took place at ca. $1.87 \mathrm{Ga}$.

Titanite from the Kisko fm yielded an age of $1798 \pm 3$ Ma. Titanite ages close to ca. 1.8 Ga have been reported from other areas in southern Finland, 1764 Ma by Korsman et al. (1984), $1818 \mathrm{Ma}$ by Patchett and Kouvo (1986) and 1804 Ma by Suominen (1991). This ca. $1.80 \mathrm{Ga}$ age might indicate a reheating of the crust or cooling down to the blocking temperature of titanite at that time. The latter explanation is preferred because highT/low-P granulite facies metamorphism in the adjacent West Uusimaa area probably occurred only marginally earlier at ca. 1.83-1.81 Ga (Schreurs \& Westra 1986, Korsman et al. 1999). 


\section{Tectonic setting of the Orijärvi area}

The field evidence, geochemistry, age determinations and previously published data are summarized below in order to interpret the tectonic setting of the volcanic formations in the Orijärvi area and discuss its relationships with volcanic formations in other parts of the Svecofennian Orogen.

In the Orijärvi fm, characterized by bimodal volcanism, the geochemical composition of mafic volcanic rocks at low stratigraphic levels tentatively shows an oceanic-arc-type chemistry with a distinct subduction component. Higher up in the stratigraphy the volcanic rocks get more evolved. This evolution is typical for volcanic rocks in oceanic arcs during thickening of the volcanic pile (e.g. Macdonald et al. 2000). This interpretation is, however, hampered by the bimodality of the formation, since bimodal volcanism is often associated with rifting where the silicic end member is derived from melting of an older ensialic crust (e.g. Wever \& Storey 1992). In the study area the $\varepsilon_{\mathrm{Nd}}(1.89 \mathrm{Ga})$ value of -0.7 for the Orijärvi granodiorite (Huhma 1986, see also Rämö et al. 2001) indicates contribution of an older crustal component for the felsic synvolcanic magmatism. Other features that might indicate extensional tectonics and subsiding subaqueous basin(s) include (i) limestones and iron formations and (ii) $\mathrm{Cu}-\mathrm{Zn}-\mathrm{Pb}$ mineralizations. The obvious subduction component in the mafic rocks, however, strongly points to a subduction-related origin for the Orijärvi fm. Therefore, we suggest that the Orijärvi fm started to form in an oceanic volcanic arc setting where a pre-arc component was incorporated through subduction, either through sediment subduction or subduction of rifted Archaean or older Palaeoproterozoic crustal blocks (see Lahtinen \& Huhma 1997).

The Kisko formation shows evidence of thicker, evolved crust and "normal" volcanic arc-type (e.g. Gill 1981) chemistry, with rock types ranging from basalts to rhyolites. Field observations suggest that it conformably overlies the Orijärvi fm with a break in volcanic activity manifested by greywackes and mica schists. We therefore suggest that the Kisko fm and the Orijärvi fm are parts of the same semicontinuously growing volcanic arc.

The Salittu fm is dominated by ultramafic and mafic volcanic rocks with oceanic affinities, which makes it different to the underlying formations. Crustal contamination is indicated only in samples close to formation boundaries. Ultramafic volcanism, minor sedimentary intercalations and the lack of contamination suggest crustal extension that caused eruption of fertile, enriched mantle. The nearly juvenile $\varepsilon_{\mathrm{Nd}}(1.89 \mathrm{Ga})$ value of +3.1 (Huhma 1986) for a picrite indicates a short crustal residence time for the source. Field evidence suggest that this formation was formed at the same time or after the Kisko fm. Therefore, although not dated, the age of the Salittu formation is probably $1880 \mathrm{Ma}$. Considering that the volcanism took place after the arc-type volcanism, we interpret this extensional stage as a back-arc (or intra-arc) rift.

The mafic volcanism in the Toija fm is transitional between the arc-type and the ocean-floortype volcanism. As in the Orijävi fm, the lithology is bimodal with marble intercalations. Although geographically adjacent, the two formations are separated by the prominent Kisko Shear Zone (Fig. 1) and they cannot be correlated since both mafic and felsic volcanic rocks are geochemically different. A picritic flow or dyke occurs in the upper part of the formation, suggesting that the Toija fm conformably underlies the Salittu fm. Considering the stratigraphical position and geochemistry of mafic rocks in the Toija fm, a backarc basin setting is favoured. Therefore, we suggest that rifting of the arc commenced with bimodal volcanism in the Toija fm and further rifting produced ultramafic and mafic volcanism in the Salittu fm.

The data suggest that all four formations in the Orijärvi area are parts of the same volcanic arc system. There is no evidence of exotic terranes in the study area.

\section{Regional tectonics}

The tectonic setting of the Orijärvi area resembles a modern volcanic arc with back-arc basin, and regional aspects are discussed below in the light of this interpretation. The volcanic formations are 
compared both along and across the east-west trending belt and possible correlations between the different areas are made.

To the east of the Orijärvi area, no comprehensive investigations of volcanic rocks have been done. In southeastern Finland, Kousa (1985) and Makkonen (1996) described basaltic and ultramafic volcanic rocks with tholeiitic major element trends. If those rocks can be correlated with the Salittu fm of this study, it indicates that rifting and formation of a back-arc basin was a large scale event, probably extending all along the SSAC, and corresponding to the area that Rämö et al. (2001) describe as Terrane I within the Svecofennian Orogen in Finland.

Towards the west, the Uusimaa Belt extends to the Kemiö island and Turku Archipelago. Lindroos and Ehlers (1994) described bimodal volcanic rocks intercalated with marbles from Vestlax, Kemiö island. The chemistry of these volcanic rocks cannot be directly compared with those of the Orijärvi volcanic rocks. The mafic/intermediate pillow lavas indicate a similarity with the lavas of the Toija fm grossly showing a MORB-type chemistry. Therefore, a similar magma source is indicated. Felsic rocks, however, more resemble the felsic rocks from the Orijärvi fm with a salient negative $\mathrm{Eu}$ anomaly. Because mafic rocks more sensitively reflect tectonic settings, we tentatively correlate the Toija fm with the Vestlax volcanic rocks. This suggests that the Vestlax rocks formed during an initial back-arc rifting stage. Continued rifting is indicated by the NaguKorpo formation, northwest of Kemiö, where ultramafic flows are encountered. According to Ehlers et al. (1986), the geochemistry of that formation indicates a within-plate setting which predates the arc-type volcanism. We, however, interpret that the Toija and Salittu formations, possible analogues, postdate the arc volcanism.

To the north and northwest of the Orijärvi area the geology is dominated by a late-orogenic granite, known as the Perniö granite (Selonen et al. 1996), and to the northeast and east supracrustal rocks of the Uusimaa Belt continue as bimodal volcanic rocks intercalated with ultramafic volcanic rocks and marbles (Härme 1958, Schreurs et al.
1986). The presence of ultramafic rocks and marbles suggest that back-arc basin extends towards north to the Somero area, which is characterized by arc-type volcanic rocks of the Häme Belt (Hakkarainen 1994, Lahtinen 1996).

During the recent years it has been repeatedly suggested that the Tampere Belt and the Häme Belt are not parts of the same volcanic arc. On the basis of $\mathrm{Pb}$ isotopes, Sundblad (1991) proposed a terrane boundary between the Tampere Belt and the Häme Belt. Differences in geochemical composition of igneous rocks in these belts and the presence of MORB-type lavas in the Pirkanmaa Belt (Peltonen 1995) also point to different settings. Therefore, Lahtinen $(1994,1996)$ proposed a suture zone between the two belts (Fig. 1a). Data on $\mathrm{Sm}-\mathrm{Nd}$ and $\mathrm{Pb}$ isotopes provide further evidence for different terranes (Rämö et al. 2001). U$\mathrm{Pb}$ age data on synorogenic intrusions also support this (Väisänen et al. 2002) and, finally, the $\mathrm{U}-\mathrm{Pb}$ age data on volcanic rocks in this study show that volcanic activity was still going on in the SSAC (Orijärvi) while the CSAC was already deformed and metamorphosed. It is, therefore, feasible to consider the Häme Belt as belonging to the same original arc system as the Uusimaa Belt, including the Orijärvi area. The mature Kisko fm has similarities with the volcanic rocks of the Häme Belt (Hakkarainen 1994, Lahtinen 1996), and we tentatively correlate these formations with each other. If correct, these belts were rifted apart during back-arc (or intra-arc) basin opening and, in this respect, the Häme Belt can be regarded as a remnant arc. Rämö et al. (2001) divide the southernmost terrane into two isotopically different domains and draw a line between the more juvenile northern part and the less juvenile southern part. We propose that this line might roughly coincide with the arc and back-arc basin boundary.

The correlation between the geology of the Bergslagen area in central Sweden and southwestern Finland has often been debated. Lundström and Papunen (1986) tentatively correlated the two areas on the basis of lithology, ore deposits and deformation but also pointed out the differences, e.g. in ore types. Lundström (1987) emphasized that stratigraphy in the Bergslagen area is domi- 
nated by felsic volcanic rocks. Mafic rocks occur only in the easternmost part of the area, but in Finland they are more common. He suggested that lateral variations in rock types are responsible for differences, not fundamentally different settings. Sundblad (1991) studied $\mathrm{Pb}$ isotope compositions of the ore deposits and proposed a clear correlation between these areas. $\varepsilon_{\mathrm{Nd}}$ data in Bergslagen (Valbracht et al. 1991, Kumpulainen et al. 1996) clearly show incorporation of older crustal material and Allen at al. (1996) consider the Bergslagen area as a continental back-arc basin. In Finland, an isotopically older component is found in the southernmost part of the SSAC (Rämö et al. 2001), but in this part of the belt there are mafic volcanic rocks that according to geochemical compositions carry a pronounced subduction component. Therefore, although at large the correlation between these areas is justified, more detailed data, especially on isotopes, is needed to get further in the discussion.

\section{CONCLUSIONS}

On the basis of field observations, geochemistry, radiometric age determinations and comparison of the data with data from previous investigations the following conclusions can be made:

- In the Orijärvi area four different formations with different geological characteristics are identified. The rock types and their chemical composition resemble modern arc and back-arc basin equivalents.

- The bimodal Orijärvi formation is the oldest and includes the synvolcanic Orijärvi granodiorite. The mafic volcanic rocks show a volcanic arc-type chemistry with a pronounced subduction component. A rhyolite from this formation was dated and yielded a U-Pb zircon age of 1895.3 \pm 2.4 Ma.

- The overlying Kisko formation shows an evolved arc-type geochemistry. A dacite from this formation was dated and yielded a U-Pb zircon age of $1878.2 \pm 3.4 \mathrm{Ma}$.

- The Salittu formation, evidently overlying the Kisko formation, contains tholeiitic basalts and picrites that show E-MORB-type chemistry. The formation is interpreted to have formed in a back-arc or intra-arc setting.

- The Toija formation contains bimodal volcanic rocks, metapelites and marbles that are interpreted to have formed in an initial back-arc rift.

- The volcanic rocks of the Orijärvi area represent the early arc, evolved arc and back-arc basin resembling an ideal oceanic volcanic arc system.

- To the east and west of the Orijärvi area, no volcanic units unequivocally similar to the arctype Orijärvi and Kisko formations are known but, instead, the volcanic rocks in these areas were evidently emplaced in a rift-related setting.

- To the north, the volcanic rocks of the Häme Belt are tentatively correlated with the Kisko formation and represent a rifted remnant arc.

- Correlation with the Bergslagen area in central Sweden is plausible but needs more data in order to be well constrained.

ACKNOWLEDGEMENTS. Discussions with Professor Krister Sundblad were very helpful to formulate the ideas in the final stage of this study. Olavi Selonen reviewed an early version of the manuscript, and the Bulletin reviewers Raimo Lahtinen and Pär Weihed suggested numerous improvements to the manuscript. Comments by Yrjö Kähkönen also substantially improved the manuscript. This study was funded by the Lithosphere Graduate School. Additional funding was received from the Ella and Georg Ehrnrooth Foundation, the Abo Akademi Foundation, the Sohlberg Foundation, and the Turku University Foundation.

\section{REFERENCES}

Allen, R.L., Lundström, I., Ripa, M., Simeonov, A. \& Christofferson, H. 1996. Facies analysis of a $1.9 \mathrm{Ga}$, continental margin, back-arc, felsic caldera province with diverse $\mathrm{Zn}-\mathrm{Pb}-\mathrm{Ag}-(\mathrm{Cu}-\mathrm{Au})$ sulfide and $\mathrm{Fe}$ oxide deposits, Bergslagen region, Sweden. Economic Geology $91,979-1008$. 
Claesson, S., Huhma, H., Kinny, P.D. \& Williams, I.S. 1993. Svecofennian detrital zircon ages - implications for the Precambrian evolution of the Baltic Shield. Precambrian Research 64, 109-130.

Colley H. \& Westra, L. 1987. The volcano-tectonic setting and mineralisation of the early Proterozoic Kemiö-Orijärvi-Lohja belt, SW Finland. In: Pharaoh, T.C., Beckinsale, R.D. \& Rickard, D. (eds.) Geochemistry and Mineralisations of Proterozoic Volcanic Suites. Geological Society of London, Special Publications 33, 95-107.

Doppe, R.T.M., Oen, I.S. \& Verdurmen, E.A.T. 1995. U$\mathrm{Pb}$ zircon ages of metatuffites and Older Granite from the Tunaberg area, SE Bergslagen. Geologie en Mijnbouw 74, 129-136.

Ehlers, C., Lindroos, A. \& Jaanus-Järkkälä, M. 1986. Stratigraphy and geochemistry in the Proterozoic mafic volcanic rocks of the Nagu-Korpo area, SW Finland. Precambrian Research 32, 307-318.

Ehlers, C., Lindroos, A., \& Selonen, O. 1993. The late Svecofennian granite-migmatite zone of southern Finland - a belt of transpressive deformation and granite emplacement. Precambrian Research 64, 295-309.

Eklund, O., Konopelko, D., Rutanen, H., Fröjdö, S. \& Shebanov, A.D. 1998. 1.8 Ga Svecofennian post-collisional shoshonitic magmatism in the Fennoscandian shield. Lithos 45, 87-108.

Eskola, P. 1914. On the petrology of the Orijärvi region in southwestern Finland. Bulletin de la Commission géologique de Finlande 40. 279 p.

Eskola, P. 1915. Om sambandet mellan kemisk och mineralogisk sammansättning hos Orijärvitraktens metamorfa bergarter. English summary: On the relations between the chemical and mineralogical compositions in the metamorphic rocks of the Orijärvi region. Bulletin de la Commission géologique de Finlande 44. 145 p.

Gill, J. 1981. Orogenic Andesites and Plate Tectonics. Berlin: Springer-Verlag. 390 p.

Hakkarainen, G. 1994. Geology and geochemistry of the Hämeenlinna-Somero Volcanic Belt, southwestern Finland: a Paleoproterozoic island arc. Geological Survey of Finland, Special Paper 19, 85-100.

Härme, M. 1958. Turku. The general geological map of Finland 1: 400 000, Pre-Quaternary rocks, sheet B1. Geological Survey of Finland.

Hietanen, A. 1975. Generation of potassium-poor magmas in the northern Sierra Nevada and the Svecofennian in Finland. Journal of Research, U.S. Geological Survey 3, 631-645.

Hughes, C.J. 1973. Spilites, keratophyres and igneous spectrum. Geological Magazine 109, 513-527.

Huhma, H. 1986. Sm-Nd, U-Pb and Pb-Pb isotopic evidence for the origin of the early Proterozoic Svecokarelian crust in Finland. Geological Survey of Finland, Bulletin $337.48 \mathrm{p}$.

Kähkönen, Y. 1999. Stratigraphy of the central parts of the Palaeoproterozoic Tampere Schist Belt, southern Finland: review and revision. Bulletin of the Geological Society of Finland 71, 13-29.
Kähkönen, Y., Huhma, H. \& Aro, K. 1989. U-Pb zircon ages and $\mathrm{Rb}$-Sr whole-rock isotope studies of early Proterozoic volcanic and plutonic rocks near Tampere, southern Finland. Precambrian Research 45, 27-43.

Kilpeläinen, T. 1998. Evolution and 3D modelling of the structural and metamorphic patterns of the Palaeproterozoic crust in the Tampere-Vammala area, southern Finland. Geological Survey of Finland, Bulletin 397. 124 p.

Koistinen, T. 1992. Temporary map of Pre-Quaternary rocks, 1 : 100 000, Sheet 2014 Tammisaari. Geological Survey of Finland.

Korsman, K., Hölttä, P., Hautala, T. \& Wasenius, P. 1984. Metamorphism as an indicator of evolution and structure of crust in Eastern Finland. Geological Survey of Finland, Bulletin 328. 40 p.

Korsman, K., Korja, T., Pajunen, M., Virransalo, P. \& GGT/SVEKA Working Group 1999. The GGT/SVEKA Transect: structure and evolution of the continental crust in the Palaeproterozoic Svecofennian orogen in Finland. International Geology Review 41, 287-333.

Kousa, J. 1985. Rantasalmen tholeiittisista ja komatiittisista vulkaniiteista. Summary: The tholeiitic and komatiitic metavolcanics in Rantasalmi, Southeastern Finland. Geologi 37, 17-22.

Kumpulainen, R., Mansfeld, J., Sundblad, K., Neymark, L. \& Bergman, T. 1996. Stratigraphy, age and Sm-Nd isotope systematics of the country rocks to $\mathrm{Zn}-\mathrm{Pb}$ sulfide deposits, Åmmeberg district, Sweden. Economic Geology 91, 1009-1021.

Krogh, T.E. 1973. A low-contamination method for hydrothermal decomposition of $\mathrm{U}$ and $\mathrm{Pb}$ for isotopic age determinations. Geochimica et Cosmochimica Acta 37, 485-494.

Lahtinen, R. 1994. Crustal evolution of the Svecofennian and Karelian domains during 2.1-1.79 Ga, with special emphasis on the geochemistry and origin of 1.93-1.91 $\mathrm{Ga}$ gneissic tonalites and associated supracrustal rocks in the Rautalampi area, central Finland. Geological Survey of Finland, Bulletin 378. 128 p.

Lahtinen, R. 1996. Geochemistry of Palaeproterozoic supracrustal and plutonic rocks in the Tampere-Hämeenlinna area, southern Finland. Geological Survey of Finland, Bulletin 389. 113 p.

Lahtinen, R. \& Huhma, H. 1997. Isotopic and geochemical constraints on the evolution of the 1.93-1.79 Ga Svecofennian crust and mantle in Finland. Precambrian Research 82, 13-34.

Latvalahti, U. 1979. Cu-Pb-Zn ores in the Aijala-Orijärvi area, Southwest Finland. Economic Geology 74, 10351059.

Le Bas, M.J. 2000. IUGS reclassification of high-Mg and picritic volcanic rocks. Journal of Petrology 41, 14671470.

Le Maitre, R.W. (ed.) 1989. A Classification of Igneous Rocks and Glossary of Terms. Oxford: Blackwell. 193 p. 
Leybourne, M., Van Wagoner, N.A. \& Ayres, L.D. 1997. Chemical stratigraphy and petrogenesis of the early Proterozoic Amisk Lake volcanic sequence, Flin Flon-Snow Lake greenstone belt, Canada. Journal of Petrology 38, 1541-1564.

Lindroos, A. \& Ehlers, C. 1994. Emplacement, deformation and geochemistry of bimodal volcanics in Vestlax, SW Finland. Geological Survey of Finland, Special Paper 18, 173-184.

Ludwig, K.R. 1991. PbDat 1.21 for MS-dos: A computer program for IBM-PC Compatibles for processing raw $\mathrm{Pb}-\mathrm{U}-\mathrm{Th}$ isotope data. Version 1.07. U.S. Geological Survey, Open File Report, 88-542. 35 p.

Ludwig, K.R. 1998. Isoplot/Ex Version 1.00. Berkeley Geochronological Center, Special Publication 1. 43 p.

Lundström, I. 1987. Lateral variations in supracrustal geology within the Swedish part of the southern Svecokarelian volcanic belt. Precambrian Research 35, 353365.

Lundström, I., Allen, R.D., Persson, P.-O. \& Ripa, M. 1998. Stratigraphies and depositional ages of Svecofennian, Palaeoproterozoic metavolcanic rocks in E. Svealand and Bergslagen, south central Sweden. GFF 120, 315-320.

Lundström, I. \& Papunen, H. (eds.) 1986. Mineral deposits of southwestern Finland and the Bergslagen province, Sweden. Sveriges Geologiska Undersökning, Ser. Ca 61. 44 p.

Macdonald, R., Hawkesworth, C.J. \& Heath, E. 2000. The Lesser Antilles volcanic chain: a study in arc magmatism. Earth-Science Reviews 49, 1-79.

Mäkelä, U. 1989. Geological and geochemical environments of Precambrian sulphide deposits in southwestern Finland. Annales Academiae Scientiarum Fennicae, Series A. III. Geologica - Geographica 151. 102 pp.

Makkonen, H. 1996. 1.9 Ga tholeiitic magmatism and related Ni-Cu deposition in the Juva area, SE Finland. Geological Survey of Finland, Bulletin 386. 101 p.

Middlemost, E.A.K. 1985. Magmas and Magmatic Rocks. London: Longman. 266 p.

Mouri, H., Korsman, K. \& Huhma, H. 1999. Tectono-metamorphic evolution and timing of the melting prosesses in the Svecofennian Tonalite-Trondhjemite Migmatite Belt: An example from Luopioinen, Tampere area, southern Finland. Bulletin of the Geological Society of Finland 71, 31-56.

Nironen, M. 1989. Emplacement and structural setting of granitoids in the early Proterozoic Tampere and Savo Schist Belts, Finland - implications for contrasting crustal evolution. Geological Survey of Finland, Bulletin $346.83 \mathrm{p}$.

Nironen, M. 1997. The Svecofennian orogen: a tectonic model. Precambrian Research 86, 21-44.

Nironen, M. 1999. Structural and magmatic evolution in the Loimaa area, southwestern Finland. Bulletin of the Geological Society of Finland 71, 57-71.

Nironen, M., Korja, A., Lahtinen, R., \& Tuisku, P. 2000. Crustal boundaries of East European Craton - keys to Proterozoic amalgamation. In: Pesonen, L.J., Korja A.
\& Hjelt S-E. (eds.) Lithosphere 2000: A symposium on the structure, composition and evolution of the lithosphere in Finland. Geological Survey of Finland, Espoo, October 4-5, 2000. Institute of Seismology, University of Helsinki, Report S-41, 121-128.

Patchett, J. \& Kouvo, O. 1986. Origin of continental crust of 1.9-1.7 Ga age: $\mathrm{Nd}$ isotopes and $\mathrm{U}-\mathrm{Pb}$ zircon ages in the Svecokarelian terrain of South Finland. Contributions to Mineralogy and Petrology 92, 1-12.

Pearce, J.A. 1983. Role of subcontinental lithosphere in magma genesis at active continental margins. In: Hawkesworth, C.J. \& Norry, M.J. (eds.) Continental Basalts and Mantle Xenoliths. Nantwich: Shiva, 230249.

Pearce, J.A. 1996. A user's guide to basalt discrimination diagrams. In: Wyman, D.A. (ed.) Trace Element Geochemistry of Volcanic Rocks: Applications for Massive Sulfide Exploration. Geological Association of Canada, Short Course Notes 12, 79-113.

Pearce, J.A., Harris, N.B.W. \& Tindle, A.G. 1984. Trace element discrimination diagrams for the tectonic interpretation of granitic rocks. Contributions to Mineralogy and Petrology 25, 956-983.

Pearce, J.A. \& Peate, D.W. 1995. Tectonic implications of the composition of volcanic arc magmas. Annual Review of Earth and Planetary Sciences 23, 251-285.

Peltonen, P. 1995. Petrogenesis of ultramafic rocks in the Vammala Nickel Belt: implications for crustal evolution of the early Proterozoic Svecofennian arc terrane. Lithos 34, 253-274.

Ploegsma, M. \& Westra, L. 1990. The Early Proterozoic Orijärvi triangle (southwest Finland): a key area on the tectonic evolution of the Svecofennides. Precambrian Research 47, 51-69.

Rajavuori, L. \& Kriegsman, L.M. 2000. The role of fluorine in orthoamphibole dominated $\mathrm{Pb}-\mathrm{Zn}-\mathrm{Cu}$ deposits: preliminary results. In: Weihed, P. \& Martinsson, O. (eds.) 2nd GEODE-Fennoscandian shield field workshop on Palaeproterozoic and Archaean greenstone belts and VMS districts in the Fennoscandian Shield. 28.81.9.2000, Gällivare-Kiruna, Sweden, 33-35.

Rämö, O.T., Vaasjoki, M., Mänttäri, I., Elliott, B.A. \& Nironen, M. 2001. Petrogenesis of the post-kinematic magmatism of the Central Finland Granitoid Complex I; radiogenic isotope constraints and implications for crustal evolution. Journal of Petrology 42, 1971-1993.

Reinikainen, J. 2001. Petrogenesis of Paleoproterozoic marbles in the Svecofennian Domain, Finland. Geological Survey of Finland. Report of Investigations 154. 84 pp.

Schneiderman, J.S. \& Tracy, R.J. 1991. Petrology of orthoamphibole-cordierite gneisses from the Orijärvi area, Southwestern Finland. American Mineralogist 76, 942955.

Schreurs, J., Van Kooperen, P. \& Westra, L. 1986. Ultramafic metavolcanic rocks of early Proterozoic age in West-Uusimaa, SW-Finland. Neues Jahrbuch für Mineralogie. Abhandlungen 155, 185-201.

Schreurs, J. \& Westra. L. 1986. The thermotectonic evo- 
lution of a Proterozoic, low pressure, granulite dome, West Uusimaa, SW Finland. Contributions to Mineralogy and Petrology 93, 236-250.

Schumacher, J. \& Czank, M. 1987. Mineralogy of tripleand double-chain pyriboles from Orijärvi, southwest Finland. American Mineralogist 72, 345-352.

Selonen, O., Ehlers, C. \& Lindroos, A. 1996. Structural features and emplacement of the late Svecofennian Perniö granite sheet in southern Finland. Bulletin of the Geological Society of Finland 68, 5-17.

Smith, I.E.M., Worthington, T.J., Price, R.C. \& Gamble, J.A. 1997. Primitive magmas in arc-type volcanic associations: examples from the Southwest Pacific. The Canadian Mineralogist 35, 257-273.

Smith, M.S., Dymek, R.F. \& Schneiderman, J.S. 1992. Implications of trace element geochemistry for the origin of cordierite-orthoamphibole rocks from Orijärvi, SW Finland. Journal of Geology 100, 545-559.

Stacey, J.S. \& Kramers, J.D. 1975. Approximation of terrestrial lead isotope evolution by a two-stage model. Earth and Planetary Science Letters 26, 207-221.

Stern, R.A., Syme, E.C., Bailes, A.H. \& Lucas, S.B. 1995a. Paleoproterozoic (1.90-1.86 Ga) arc volcanism in the Flin Flon Belt, Trans-Hudson orogen, Canada. Contributions to Mineralogy and Petrology 119, 117-141.

Stern, R.A., Syme, E.C. \& Lucas, S.B. 1995b. Geochemistry of $1.9 \mathrm{Ga}$ MORB- and OIB-like basalts from Amisk collage, Flin Flon belt, Canada: Evidence for an intraoceanic origin. Geochimica et Cosmochimica Acta 59, 3131-3154.

Sun, S.S. \& McDonough, W.F. 1989. Chemical and isotopic systematics of oceanic basalts: implications for mantle compositions and processes. In: Saunders, A.D. \& Norry, M.J. (eds.) Magmatism in the Ocean Basins. Geological Society, London, Special Publication 42, 313-345.

Sundblad, K. 1991. Svecofennian lead isotopic provinces in the Baltic Shield. In: Pagel, M. \& Leroy, J.L. (eds.) Source, Transport and Deposition of Metals. Rotterdam: Balkema, 355-358.

Suominen, V. 1991. The chronostratigraphy of southwestern Finland with special reference to Postjotnian and Subjotnian diabases. Geological Survey of Finland, Bulletin $356.100 \mathrm{p}$.

Tuominen, H.V. \& Mikkola, T. 1950. Metamorphic MgFe enrichment in the Orijärvi region as related to folding. Bulletin de la Commission géologique de Finlande 150, 67-92.
Vaasjoki, M. 1977. Rapakivi granites and other postorogenic rocks in Finland: their age and the lead isotopic composition of certain associated galena mineralizations. Geological Survey of Finland, Bulletin 294. 64 p.

Vaasjoki, M. 1994. Valijärven hapan vulkaniitti: minimi Hämeen liuskejakson iäksi. English Summary: Radiometric age of a meta-andesite at Valijärvi, Häme schist zone, southern Finland. Geologi 46, 91-92.

Vaasjoki, M. \& Sakko, M. 1988. The evolution of the Raahe-Ladoga zone in Finland: isotopic constraints. Geological Survey of Finland, Bulletin 343, 7-32.

Väisänen, M. \& Hölttä, P. 1999. Structural and metamorphic evolution of the Turku migmatite complex, southwestern Finland. Bulletin of the Geological Society of Finland 71, 177-218.

Väisänen, M., Mänttäri, I. \& Hölttä, P. 2002. Svecofennian magmatic and metamorphic evolution of southwestern Finland as revealed by U-Pb zircon SIMS geochronology. Precambrian Research 116, 111-127.

Väisänen, M., Mänttäri, I., Kriegsman, L.M. \& Hölttä, P. 2000. Tectonic setting of post-collisional magmatism in the Palaeoproterozoic Svecofennian orogen, SW Finland. Lithos 54, 63-81.

Valbracht, P.J., Helmers, H. \& Beunk, F.F. 1991. Early Proterozoic continental tholeiites from western Bergslagen, central Sweden, I. Petrology, geochemical petrogenesis and geotectonic setting. Precambrian Research 52, 187-214.

Van Duin, J.A. 1992. The Turku granulite area, SW Finland: a fluid-absent Svecofennian granulite occurrence. $\mathrm{PhD}$ thesis, Vrije Universiteit, Amsterdam. 234 p.

Welin, E. 1987. The depositional evolution of the Svecofennian supracrustal sequence in Finland and Sweden. Precambrian Research 35, 95-113.

Wever, H.E. \& Storey, B.C. 1992. Bimodal magmatism in northeast Palmer Land, Antarctic Peninsula: geochemical evidence for a Jurassic ensialic back-arc basin. Tectonophysics 205, 239-259.

Wood, D.A. 1980. The application of a Th-Hf-Ta diagram to problems of tectonomagmatic classification and to establish the nature of crustal contamination of basaltic lavas of the British Tertiary Volcanic Province. Earth and Planetary Science Letters 50, 11-30. 
Appendix 1. Localities for analyses. For lithology and other symbols, see Fig. 1.

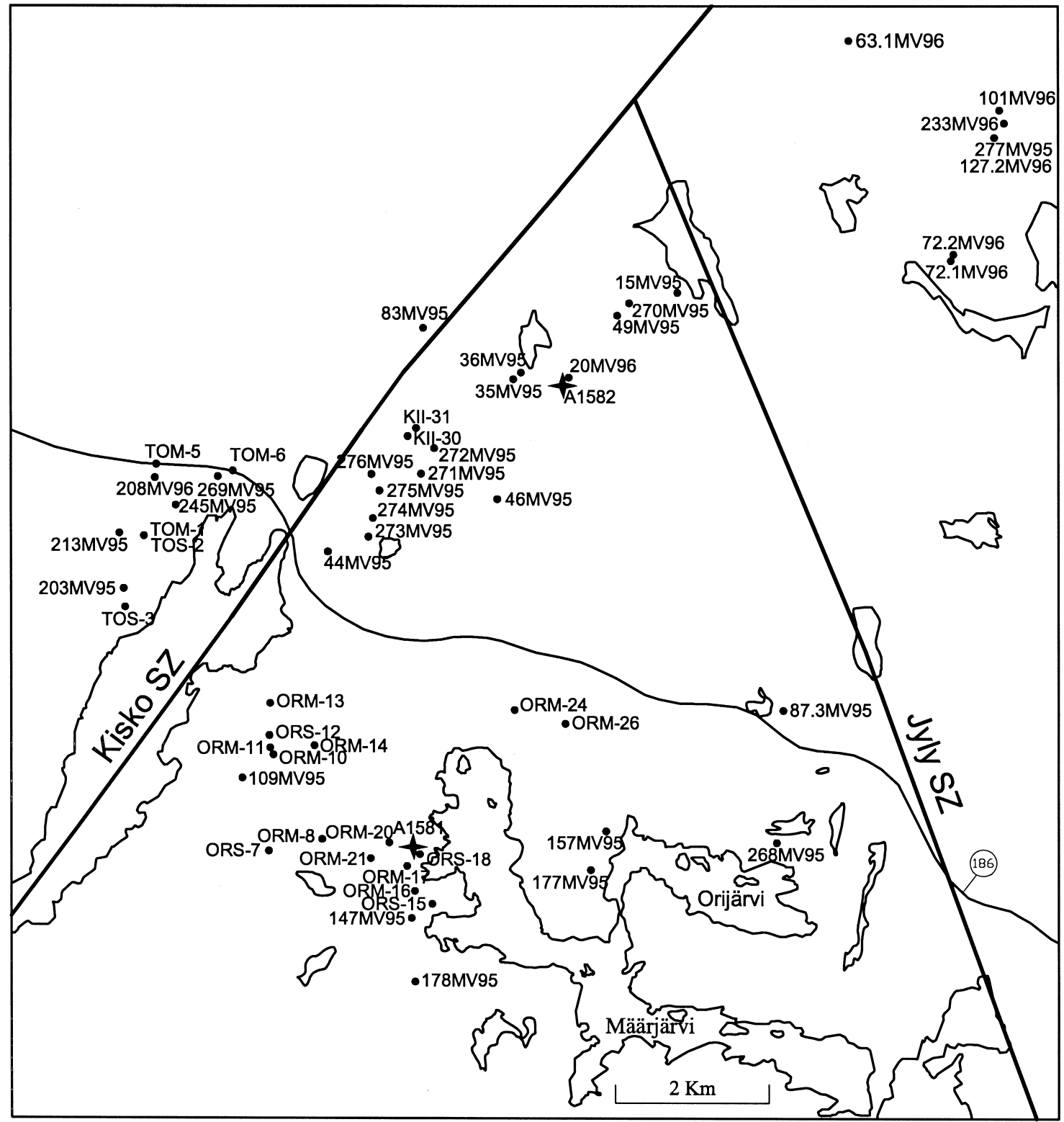

\footnotetext{
- Locality for geochemical analysis $\quad+$ Locality for U-Pb dating
} 